\title{
Lord Howe Island Psocoptera (Insecta)
}

\author{
C.N. SMITHERS \\ Research Associate, Australian Museum, 6 College Street, Sydney NSW 2010, Australia \\ smithers@sydney.net
}

\begin{abstract}
A brief history of collecting Psocoptera on Lord Howe Island is given. One new genus, Mauropsocus (Pseudocaeciliidae: Zelandopsocinae), and three new species, Mauropsocus monteithi, Lepolepis trifasciata (Lepidopsocidae) and Nimbopsocus huttoni (Myopsocidae) are described. An additional new genus and species is noted but not formally described and named because adult material has not yet been found. Twentyseven species of Psocoptera are now known from Lord Howe of which fourteen are probably endemic to the island. Of the thirteen non-endemic species eight have widespread distributions beyond the island (some being found in domestic situations); three occur otherwise only in Australia and one is known only from Norfolk Island. One species occurs in Australia, New Caledonia, Norfolk Island and New Zealand. It is anticipated that the fauna is not yet completely known but most of the endemic species are members of the related families Pseudocaeciliidae, Philotarsidae and Elipsocidae. Distribution of the species is summarized in a table.
\end{abstract}

SMITHERS, C.N., 2007. Lord Howe Island Psocoptera (Insecta). Records of the Australian Museum 59(1): 9-26.

The first recorded psocopteran from Lord Howe Island, a female specimen of Aaroniella howensis Smithers \& Thornton, was collected by Ms Zenta Liepa in 1955 and described in 1975. This and material collected by the author in November 1969, February 1971 and August 1971 and by Geoffrey Holloway in September 1971 and March 1974 formed the basis of the first paper on the Psocoptera of Lord Howe Island (Smithers \& Thornton, 1975). The author visited the island again in February 1977 (Smithers, 1979). Between September 1978 and October 1979 Tim Kingston collected Psocoptera as part of a general insect survey and in 1979 Geoff. Monteith, of the Queensland Museum, made what was then the most comprehensive collection of Psocoptera from Lord Howe. Kingston made a small collection in 1980 and Patrick Huber, in 1992-1993, collected a few specimens during a survey of insects associated with the inflorescences of the economically important Thatch Palm, Howea forsteriana (C. Moore and F. Muell.) Becc. (Smithers, 1995). The biggest collection to date is that made during the Lord Howe Island Invertebrate Biodiversity Survey in which several collectors, based at the Australian Museum, using a variety of collecting techniques, amassed a substantial amount of material during several visits. Since then Ian Hutton has provided additional material collected between 2000 and 2003. Some of the material from the Lord Howe Invertebrate Biodiversity Survey has no designated individual collector; in the lists of material studied in this paper these specimens are referred to as being collected by LHIS.

Except where indicated otherwise specimens collected by Monteith will be returned to the Queensland Museum. Other material is in the Australian Museum. Nymphs are not designated as type material.

Full synonymies and references to the species can be found in Smithers $(1967,1996)$ and Lienhard and Smithers (2002) or other references given in this paper. Plant names used are as in Wilson (1994), with later amendments where necessary. Vegetation types mentioned in association with some of the material collected by Monteith are described by Pickard (1983); these are referred to as Pickard veg on the specimen labels and hence in the text of this paper.

In the species descriptions the following abbreviations are used: $\mathrm{F}=$ length of hind femur; $\mathrm{T}=$ length of hind tibia; $\mathrm{t} 1$,

www.australianmuseum.net.au/pdf/publications/1482_complete.pdf 
$\mathrm{t} 2, \mathrm{t} 3=$ lengths of hind tarsal segments; $\mathrm{rt}=$ relative lengths of hind tarsal segments; ct: numbers of ctenidiobothria on hind tarsal segments. Eye measurements are carried out using the method of Badonnel, i.e.: $\mathrm{IO}=$ interocular distance between compound eyes measured from above; D $=$ anteroposterior measurement of compound eye seen from above; $\mathrm{P}=$ transverse measurement of compound eye seen from above; $\mathrm{PO}=\mathrm{P} / \mathrm{D}$; nymph is abbreviated to $n$.

Comparison with collecting experience on Norfolk Island suggests that it is very likely that there are more species to be recorded from Lord Howe Island. Norfolk Island has about twice the land area of Lord Howe Island (about 34 square kilometres compared to 16 square kilometres for Lord Howe). Although Lord Howe and Norfolk have about the same number of vascular plants (459 and 445 species respectively) Lord Howe has a larger indigenous flora than Norfolk (241 spp. of vascular plants as opposed to
171 spp.) (Wilson, 1994), a much more varied topography (875 metres altitude as opposed to $316 \mathrm{~m}$.) and although subjected to less collecting effort by specialist collectors it has yielded a comparable number of species of Psocoptera (27, of which 14 appear to be endemic) to that obtained on Norfolk (21, of which 11 appear to be endemic). Fifteen species of Psocoptera have been added to the Lord Howe list in this paper whereas only five additional species have been found on Norfolk since 1978, the latest addition (in 1998) being a single, widely distributed tropical species (Smithers, Peters \& Thornton, 2000). Despite its greater (but much more disturbed) area it seems likely that most species have now been recorded for Norfolk. On the other hand, circumstances on Lord Howe suggest that more species will be found there. This possibility should be remembered when considering relationships of the Lord Howe fauna to those of other areas (Table 1).

Table 1. Distribution of Lord Howe Island Psocoptera.

\begin{tabular}{|c|c|c|c|c|c|c|}
\hline \multicolumn{7}{|l|}{ LEPIDOPSOCIDAE } \\
\hline Echmepteryx anomala & - & - & - & - & - & - \\
\hline Echmepteryx howensis & $\bullet$ & - & - & - & - & - \\
\hline Echmepteryx madagascariensis ${ }^{1}$ & 1 & - & $\bullet$ & - & - & - \\
\hline \multicolumn{7}{|l|}{ TROGIIDAE } \\
\hline Cerobasis annulata ${ }^{1,2}$ & - & ○ & $\bullet$ & - & - & - \\
\hline Cerobasis guestfalica $a^{1,2}$ & - & $\bullet$ & $\bullet$ & 0 & - & $\bullet$ \\
\hline Lepinotus inquilinus $s^{1,2}$ & - & $\bullet$ & $\bullet$ & - & - & - \\
\hline \multicolumn{7}{|l|}{ PSOQUILLIDAE } \\
\hline Stenocaecilius quercus & - & - & $\bullet$ & - & - & - \\
\hline Paracaecilius lemuris ${ }^{1}$ & - & - & $\bullet$ & - & - & - \\
\hline Valenzuela pteridii ${ }^{1}$ & - & - & $\bullet$ & - & - & - \\
\hline \multicolumn{7}{|l|}{ ECTOPSOCIDAE } \\
\hline Ectopsocus insularis ${ }^{1}$ & - & - & - & $\bullet$ & - & - \\
\hline Ectopsocus petersi & - & $\bullet$ & $\bullet$ & - & - & $\bullet$ \\
\hline \multicolumn{7}{|l|}{ PERIPSOCIDAE } \\
\hline Peripsocus milleri $^{1}$ & - & $\bullet$ & $\bullet$ & $\bullet$ & $\bullet$ & $\bullet$ \\
\hline Peripsocus similis ${ }^{1}$ & - & ○ & - & - & - & - \\
\hline \multicolumn{7}{|l|}{ PSEUDOCAECILIIDAE } \\
\hline \multicolumn{7}{|l|}{ PHILOTARSIDAE } \\
\hline Aaroniella howensis & $\bullet$ & - & - & - & - & - \\
\hline Haplophallus tandus & ○ & - & - & - & - & - \\
\hline \multicolumn{7}{|l|}{ ELIPSOCIDAE } \\
\hline Pentacladus marmoratus & $\bullet$ & - & - & - & - & - \\
\hline Prionotodrilus parvus & ○ & - & - & - & - & - \\
\hline \multicolumn{7}{|l|}{ MYOPSOCIDAE } \\
\hline Nimbopsocus huttoni $^{1}$ & $\bullet$ & - & - & - & - & - \\
\hline Nimbopsocus australis ${ }^{1}$ & - & 0 & $\bullet$ & 0 & 0 & 0 \\
\hline number of species: 27 & 14 & 9 & 11 & 5 & 2 & 5 \\
\hline
\end{tabular}

In the table $\bullet=$ species is present in the area indicated at the head of the column;

${ }^{1}$ first record for Lord Howe in this paper;

${ }^{2}$ species frequently associated with human domestic environment;

${ }^{3}$ known so far only from Lord Howe Island;

${ }^{4}$ occurs in areas other than above, in some cases almost cosmopolitan, see text for details. 


\section{Systematic treatment of Lord Howe Island Psocoptera}

\section{LEPIDOPSOCIDAE}

\section{Echmepteryx anomala Smithers \& Thornton}

Echmepteryx anomala Smithers \& Thornton, 1975. Rec. Aust. Mus. 29:456.

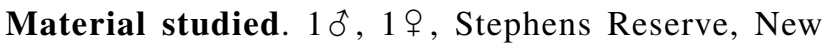
Settlement, megaphyllous broad sclerophyll forest, Howea spp., 15- 26.ii.2001, M.S. Moulds. 1 \% , Base of Round Face (Mt. Lidgbird), Far Flats, broad megaphyllous closed sclerophyll forest, 2-5.xii.2001, C. Reid. 1 $\hat{\sigma}$, eastern slope of Dawsons Point Ridge above Old Settlement, litter, closed rain forest, Drypetes/Cryptocarya (exposed), 1.xii.2000, LHIS. 1 , Stevens Reserve, 5 m, leaf litter, Howea forsteriana, 25.ix.1978, T. Kingston. 1 o, Mt. Gower, 350 m, ii.1979, T. Kingston. $2 \widehat{\delta}, 3 ㅇ$, Intermediate Hill, rainforest, 180250 m, 6.xi.1979, G.B. Monteith. 10ิ, Transit Hill, rainforest, pyrethrum knockdown, 18.x.1979, G.B. Monteith. 10, 2 우, Big Creek at Mountain Inn, pyrethrum knockdown, 11.xi.1979, G.B. Monteith. 10, Boat Harbour, rainforest, pyrethrum knockdown, 23.xi.1979, G.B. Monteith. 1 , Dawsons Ridge Top, rainforest, pyrethrum knockdown, 5.xi.1979, G.B. Monteith. 1 $\widehat{\jmath}$, Malabar Hill, rainforest, pyrethrum knockdown, 25.xi.1979, G.B. Monteith.

Distribution. Known only from Lord Howe Island.

\section{Echmepteryx (Loxopholia) howensis Smithers \& Thornton}

Echmepteryx (Loxopholia) howensis Smithers \& Thornton. 1975. Rec. Aust. Mus. 29:454.

Material studied. $2 \uparrow q, 3 n n$, c. $50 \mathrm{~m} \mathrm{~S}$ of summit of Mt. Eliza on western face, orthophyll short grass, Poa, Drypetes deplanchei, beating, 1.xii.2000, H. Smith. 10 충, 6 우 $q$, $3 n n$, small swampy area behind dunes at southern end of Lagoon Beach, turnoff to Intermediate Hill, broad sclerophyll swamp scrub, Aegiceras, Lagunaria patersonia (host H15 in field notes), beating, 8.xii.2000, G. Cassis. 1n, Western slope of Dawsons Point Ridge off North Beach Trail, closed rain forest, Drypetes/Cryptocarya (calcarenite), hostplant: Melicope polybotrya, beating, 24.xi.2000, P. Flemons, J. Tarnawski. 1n, Malabar Hill, on path to Kims Lookout, narrow sclerophyll closed scrub, Dodonaea/Cassinia, Cassinia tenuifolia, beating, 24.xi.2000, L. Wilkie, G. Carter. 1n, Lagoon Beach between rubbish tip and airstrip, closed rain forest, Drypetes/Cryptocarya, Alyxia ruscifolia, beating, 27.xi.2000, M. Elliott, N. Plunkett-Cole. 19 , $2 n n$, eastern end of Boat Harbour beach, narrow closed sclerophyll scrub, Melaleuca/Cassinia, Olea paniculata, beating, 26.xi.2000, P. Flemons, J. Tarnawski. $2 q$ $q$, Little Slope, broad-leafed herb vegetation, mixed ferns/herbs, Melaleuca howeana, beating, 30.xi.2000, P. Flemons, J. Tarnawski. $1 \hat{0}$, eastern slope of Dawsons Point Ridge above Old Settlement, closed rain forest, Drypetes/Cryptocarya (exposed), pitfall trap, 24.xi.2000 to 1.xii.2000, LHIS. 1 \% , junction of Kims Lookout trail and North Beach trail, closed rain forest, Drypetes/Cryptocarya, Drypetes deplanchei, beating, 25.xi.2000, L. Wilkie, H. Smith. 1n, Malabar
Hill, on path to Kims Lookout, narrow sclerophyll closed scrub, Dodonaea/Cassinia, Drypetes deplanchei, beating, 24.xi.2000, L. Wilkie, G. Carter. 2nn, broad megaphyllous closed sclerophyll forest, Howea belmoreana, Baloghia inophylla, beating, 30.xi.2000, P. Flemons, J. Tarnawski. $1 n$, western slope of Transit Hill, broad megaphyllous closed sclerophyll forest, Howea forsteriana, 24.xi.2000, M. Elliott, N. Plunkett-Cole. 1n, eastern slope of Malabar Ridge above Neds Beach, closed rain forest, Drypetes/ Cryptocarya, Elaeodendron curtipendulum, beating, 25.xi.2000, L. Wilkie, H. Smith. $1 n$, just behind beach at Old Gulch on western footslopes, narrow sclerophyll closed scrub, Melaleuca howeana beating, 25.xi.2000, L. Wilkie, H. Smith. 3nn, eastern slope of Dawsons Point Ridge above Old Settlement, closed rain forest, Drypetes/Cryptocarya (exposed), Drypetes deplanchei, beating, 24.xi.2000, P. Flemons, J. Tarnawski. 1n, eastern slope of Dawsons Point Ridge near top, closed rain forest, Cleistocalyx/Chionanthus, Howea belmoreana, beating, 1.xii.2000, C. Reid, H. Smith. 19 , north bank of Rocky Run Creek where coastal trail to Boat Harbour intersects, broad megaphyllous closed sclerophyll forest, Pandanus, Alyxia ruscifolia, beating, 30.xi.2000, C. Reid, H. Smith. 1 ô, on Boat Harbour walking trail, c. $200 \mathrm{~m}$ before harbour, broad megaphyllous closed sclerophyll forest, Pandanus, Atractocarpus stipularis, beating, 30.xi.2000, C. Reid, H. Smith. 2nn, eastern slopes of Roach Island, sclerophyll tall grass, Cyperus, 29.xi.2000, Lagunaria patersonia, beating, 30.xi.2000, C. Reid, H. Smith. 29 specs. eastern end of Old Settlement Beach, broad sclerophyll swamp scrub, Aegiceras, Araucaria heterophylla (host H32 in field notes), beating, 11.xii.2000, G. Cassis. $1 \hat{\sigma}$, southern end of Old Settlement Beach, 7.xii.2000, Cassinia tenuifolia, sweep sampling, 11.xii.2000, G. Cassis. 10 , Goat House walking track, c. $550 \mathrm{~m}$ from junction with Erskine Valley track, Intermediate Hill, Pandanus forsteri, hand collected, 6.xii.2000, G. Cassis. $2 n n$, c. 50 $\mathrm{m} \mathrm{S}$ of summit of Mt. Eliza on western face, orthophyll short grass, Poa, Drypetes deplanchei, beating, 1.xii.2000, H. Smith. 1 $\sigma^{\pi}$, Research Station backyard, 24-26.ii.2001, surrounded by Drypetes/Cryptocarya, closed rain forest. M.S. Moulds. 1n, southern face of Mt. Lidgbird, at base of summit tabletop, closed rain forest, Drypetes/Cryptocarya (calcarenite), leaf litter, 3.xii.2000, LHIS. 10, 2 우, near airport terminal, 15-26.ii.2001. M.S. Moulds. 1n, Stephens Reserve, New Settlement, megaphyllous broad sclerophyll forest, Howea spp. Olea paniculata, beating, 13.xii.2000,

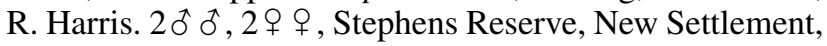
megaphyllous broad sclerophyll forest, Howea spp., 15-26.ii.2001, M.S. Moulds. 1n, Stephens Reserve, New Settlement, megaphyllous broad sclerophyll forest, Howea spp., Howea forsteriana, beating, 13.xii.2000, R. Harris, 1 to,

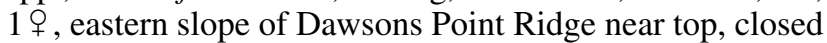
rain forest, Cleistocalyx/Chionanthus, 4-8.xii.2001, C. Reid. $1 \hat{0}$, base of Round Face (Mt. Lidgbird), Far Flats, broad megaphyllous closed sclerophyll forest, Howea belmoreana, 2-5.xii.2001, C. Reid. 1 ㅇ, eastern slope of Dawsons Point Ridge near top, closed rain forest, Cleistocalyx/Chionanthus, Drypetes deplanchei, beating, 1.xii.2000, C. Reid, H. Smith. 1 , , North Hummock (trail to Intermediate Hill), lowland mixed rain forest, Cleistocalyx/Chionanthus, Atractocarpus stipularis, beating, 3.xii.2000, P. Flemons, J. Tarnawski. 1 ㅇ, $2 \hat{\delta} \widehat{0}$, Site 8, beating fallen branches, Intermediate Hill, 100 m, leaf litter, Cleistocalyx fullagarii, Chionanthus 
quadristamineus, 24.i.1979, T. Kingston. 19 , Balls Pyramid, 24.i.1980, No collector. $1 \delta^{\star}, 2 \%$, Intermediate Hill, rainforest, 180-250 m, 6.xi.1979, G.B. Monteith. 30ิ ô, 1 ㅇ, North Bay, scrub, pyrethrum knockdown, 19.xi.1979, G.B. Monteith. $2 \widehat{\delta} \widehat{\jmath}$, Erskine Valley, rainforest, pyrethrum knockdown, 24.xi.1979, G.B. Monteith. 10, Smoking Tree Ridge, pyrethrum knockdown, 11.xi.1979, G.B. Monteith. 2 q 9 , Mountain Inn, Big Creek, pyrethrum knockdown, 11.xi.1979, G.B. Monteith. 19, Malabar Hill, pyrethrum knockdown, 25.xi.1979, G.B. Monteith.

Distribution. Known only from Lord Howe Island.

\section{Echmepteryx (Thylacopsis) madagascariensis (Kolbe)}

Thylax madagascariensis Kolbe, 1885. Berl. ent. Ztschr. 1885: 184.

Thylacopsis madagascariensis (Kolbe). Enderlein, 1911. Palaeontographica 58: 348.

Echmepteryx costalis Banks, 1931. Proc. Hawaii. ent. Soc. 7: 439.

Lepidopsocus costalis (Banks). Zimmerman, 1948. Insects of Hawaii 2: 224.

Thylacopsis albidus Badonnel, 1949. Rev. franc. Ent. 16: 25.

Echmepteryx (Thylacopsis) madagascariensis (Kolbe). Smithers, 1967. Aust. Zool. 14: 8.

Material studied. 10 , Stephens Reserve, New Settlement, megaphyllous broad sclerophyll forest, Howea spp., 26.ii.2001, M.S. Moulds.

Distribution. First record for Lord Howe Island. Previously known from Madagascar, Réunion, Isle Glorieuse, Seychelles, East Africa, Ivory Coast, Bioko Is., South America, North America, Australia, Hawaii, Bonin Is., Marianas, Kermadecs, Chagos Archipelago, New Zealand, Norfolk Island, Galapagos, Tonga, Society Islands, Indonesia, Bermuda, Jamaica, Fiji, Diego Garcìa, Chile, Hong Kong, Germany (introduced, in greenhouse).

\section{Lepolepis trifasciata n.sp.}

Material studied. 19 (HOLOTYPE) (K232557), Lagoon Beach between rubbish tip and airstrip, litter, closed rain forest, Drypetes/ Cryptocarya, 27.xii.2000, LHIS. PARATYPES: $12 \hat{0} 0,69+$, Lagoon Beach between rubbish tip and airstrip, litter, closed rain forest, Drypetes/Cryptocarya, leaf litter, 27.xi.2000, LHIS. 2 우, ridge top, northern end of Roach Island. broad-leafed herb layer, Ipomoea/Carpobrotus, pitfall trap, 29.xi-7.xii.2000, LHIS. 19 , Eastern slope of Dawsons Point Ridge above Old Settlement, closed rain forest, Drypetes/Cryptocarya (exposed), pitfall trap, 24.xi-1. xii.2000, LHIS. $2 \hat{\delta}$, southeastern aspect of Transit Hill near summit, closed rain forest, Cleistocalyx/Chionanthus, pitfall trap, 24.xi-1.xii.2000, LHIS. 10, western slope of Transit Hill, broad megaphyllous closed sclerophyll forest, Howea forsteriana, pitfall trap, 24.xi-1.xii.2000, LHIS. 19 , western face of Mt. Lidgbird, at base of summit tabletop, broad closed sclerophyll scrub, Dracophyllum/Metrosideros, pitfall trap, 25.xi-2.xii.2000, LHIS. 10 , on Boat Harbour walking trail, closed rain forest, Cleistocalyx/ Chionanthus, pitfall trap, 26.xi-3.xii.2000, LHIS. 1 \% , point where walking trail first enters Erskine Valley from coast, narrow closed sclerophyll scrub, Melaleuca/Cassinia, pitfall trap, 25.xi-2. xii.2000, LHIS. $1+$, western face of Mt. Lidgbird, at base of summit tabletop, broad closed sclerophyll scrub, Dracophyllum/ Metrosideros, pitfall trap, 25.xi-2.xii.2000, LHIS. 10, 1 ㅇ, 4nn, Little Island, coastal track to Erskine Valley, palm litter, 13.xii.2000, G. Cassis. 10 , $1 n$, on Boat Harbour walking trail, leaf litter, closed rain forest, Cleistocalyx/Chionanthus, 21.xi.2000, LHIS. 3nn, Walking trail through Erskine Valley, leaf litter, closed rain forest, Cleistocalyx/Chionanthus, LHIS. $10,3+9+3 n n$, on walking track to Erskine Valley, adjacent to Salmon Beach, leaf litter, collected at night, 10.xii.2000, G. Cassis. $1 \delta$, 2nn, Eastern aspect of Transit Hill near summit, leaf litter, narrow closed sclerophyll scrub, 19.

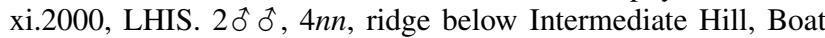
Harbour walking trail, leaf litter, 12.xii.2000, G. Cassis. 4o $\delta$, $1 n$, on Boat Harbour walking trail, c. $200 \mathrm{~m}$ before harbour, leaf litter, broad megaphyllous closed sclerophyll forest, Pandanus habitat, 21.xi.2000, LHIS. 7 specs., point where walking trail first enters Erskine Valley from coast, leaf litter, narrow closed sclerophyll scrub Melaleuca/Cassinia, 2.xii.2000, LHIS. 40ิ oิ, 2 우, $16 \mathrm{nn}$, LHI—site 9. 10 specs., southeastern aspect of Transit Hill near summit, leaf litter, closed rain forest, Cleistocalyx/Chionanthus habitat, 24.xi.2000, LHIS. $2+q$, Malabar Hill, on path to Kims Lookout, leaf litter, narrow sclerophyll closed scrub, Dodonaea/ Cassinia, 24.xi.2000, LHIS. $20^{\star}, 2$, 9 , , western slope of Malabar Ridge S of Kims Lookout trail, leaf litter, broad megaphyllous closed sclerophyll forest, Howea belmoreana, 24.xi.2000, LHIS. $2 ㅇ$, Stephens Reserve, New Settlement, megaphyllous broad sclerophyll forest, Howea spp., 15-26.ii.2001, M.S. Moulds. $6{ }^{\star}{ }^{\star}$, $3 ㅇ, 10 n n$, eastern slope of Malabar Ridge above Neds Beach, leaf litter, closed rain forest, Drypetes/Cryptocarya, 19.xi.2000, LHIS. $10,3 n n$, North Hummock (trail to Intermediate Hill), leaf litter, lowland mixed rain forest, Cleistocalyx/Chionanthus, 3. xii.2000, LHIS. 10 , $1 n$, western slope of Dawsons Point Ridge off North Beach Trail, leaf litter, closed rain forest, Drypetes/ Cryptocarya (basalt), 20.xi.2000, LHIS. 4§ $\widehat{\jmath}, 2 n n$, Malabar Hill, on path to Kims Lookout, leaf litter, narrow sclerophyll closed scrub, Dodonaea/Cassinia, 24.xi.2000, LHIS. 10, 19 , Little Island, coastal track to Erskine Valley, palm litter, 13.xii.2000, G. Cassis. $1 \hat{0}, 1$, , eastern end of Boat Harbour beach, leaf litter, narrow closed sclerophyll scrub, Melaleuca/Cassinia, 3.xii.2000, LHIS. 19 , Goat House walking track, c. $1 \mathrm{~km}$ from junction with Erskine Valley track, Intermediate Hill, leaf litter, Pandanus, 6. xii.2000, G. Cassis. 1 , , southern end of Salmon Beach, Little Island, 27.xi.2000, broad megaphyllous closed sclerophyll forest,

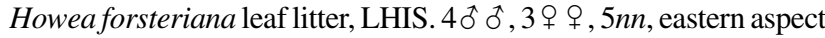
of Transit Hill near summit, narrow closed sclerophyll scrub, Melaleuca/Cassinia leaf litter, 19.xi.2000, LHIS. 19 , near Goat House Cave, various mosses, lichens and liverworts, leaf litter, 23.ii.2001, J. Tarnawski. $2 \widehat{o}^{\widehat{t}}$, eastern slope of Dawsons Point Ridge above Old Settlement, closed rain forest, Drypetes/ Cryptocarya (exposed), leaf litter, 1.xii.2000, LHIS. 20 to, 1 , western face of Mt. Lidgbird, at base of summit tabletop, broad closed sclerophyll scrub, Dracophyllum/Metrosideros, pitfall trap, 25.xi-2.xii.2000, LHIS. $1 \delta^{\star}, 4 n n$, southeastern aspect of Transit Hill near summit, closed rain forest, Cleistocalyx/Chionanthus leaf litter, 24.xi.2000, LHIS. 1n, junction of Kims Lookout trail and North Beach trail, closed rain forest, Drypetes/Cryptocarya, pitfall trap, 25.xi-2.xii.2000, LHIS. $3 \overbrace{}^{\star}{ }^{\star}, 1$ ㅇ, 5nn, Malabar Hill, on path to Kims Lookout, narrow sclerophyll closed scrub, Dodonaea/ Cassinia, leaf litter, 24.xi.2000, LHIS. 1 ô, point where walking trail first enters Erskine Valley from coast, narrow closed sclerophyll scrub, Melaleuca/Cassinia, pitfall trap, 25.xi-2.xii.2000, LHIS. $1 \delta^{\tau}, 19$, on walking track to Erskine Valley, adjacent to Salmon

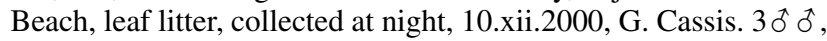
$5 n n$, Little Island, coastal track to Erskine Valley, palm leaf litter, 13.xii.2000, G. Cassis. 2 के $\widehat{o}$, Mt. Gower, north face, near creek crossing of walking track, leaf litter, Chionanthus quadristamineus, Guioa coriacea, Drypetes deplanchei, 19.v.2002, I. Hutton. 1 9 , 
Mt Gower summit on ridge between creeks 3 (most western) and 2 (middle), Pittosporum erioloma, Zygogynum, Metrosideros nervulosa, leaf litter, 25.vi.2001, Ian Hutton. 1 \%, Lagoon Beach between rubbish tip and airstrip, closed rain forest, Drypetes/ Cryptocarya, pitfall trap, 27.xi.-4.xii.2000, LHIS. 1 \% , western slopes of Roach Island, orthophyll short grass, Poa, pitfall trap, 29.xi-7.xii.2000, LHIS. 1 \% Transit Hill, 60 m, leaf litter, Chionanthus quadristamineus, Cleistocalyx fullagarii, 26.x.1979, T. Kingston. $2 q$ q , same data, 10.x.1978, T. Kingston. 1, same data, 26.x.1979, T. Kingston. 19 , same data, 8.iv.1979, T. Kingston. $10^{\star}, 19$, Clear place, leaf litter, 6.i.1980, T. Kingston. 10, south end, Settlement Beach, under bark, Lagunaria, 7.viii.2000, No collector. 19 , 2nn, Transit Hill, north slope, Queensland Museum berlesate 151, volcanic soil, Pickard veg DaCt, 18.xi.1979, G.B. Monteith. 10, 1 \% , 2nn, same data, Queensland Museum berlesate 152, volcanic soil, Pickard veg DaCt, sieved litter, 18.xi.1979, G. B. Monteith. 10, same locality, west base, Queensland Museum berlesate 118, volcanic soil, $5 \mathrm{~m}$, Pickard veg DaCt, sieved litter, 4.xi.1979, G.B. Monteith. 1ठ, same locality, north slope, Queensland Museum berlesate 137, Pickard veg Cflq, sieved litter, 18.xi.1979, G.B. Monteith. 10, 3 ㅇ $q$, North Bay, 5 m, leaf litter, Howea forsteriana, 15.xi.1978, T. Kingston. 10, North Bay, west end, $5 \mathrm{~m}$, Queensland Museum berlesate 156, Pickard veg Hf, sieved litter, volcanic soil, 19.ix.1979, G.B. Monteith. 30 oิ, 2 ㅇ 우, Old Settlement, $80 \mathrm{~m}$, litter, Drypetes deplanchei, Cryptocarya triplinervis, 18.iv.1979, T. Kingston. $3 \hat{0} \widehat{0}, 5$ ㅇ $q$, same data, 2. vi.1979, T. Kingston. 1 , , same data, 8.iv.1979, T. Kingston. 1 to, 1 ㅇ, Stevens Reserve, 5 m, leaf litter, Howea forsteriana, 1.x.1978, T. Kingston. 1 क, 1 q , same data, LHI 168, No 8, 25.ix.1978, T. Kingston. $10^{\hat{0}}$, same data, LHI 191, No 8, T. Kingston. $10^{t}, 2$ 우, same data, 30.ix.1978, T. Kingston. 1 o, Intermediate Hill, leaf litter, Cleistocalyx fullagarii, Chionanthus quadristamineus, LHI 327, No 8, 24.i.1979, T. Kingston. 2 q 9 , same locality, LHI 316,

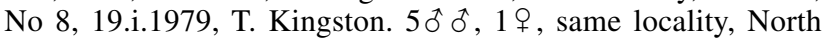
Hummock, Queensland Museum berlesate 125, volcanic soil, 180 m, Pickard veg CfLq, sieved litter, 6.xi.1979. G.B. Monteith. 1 o, 1 , Intermediate Hill, Cleistocalyx fullagarii, Chionanthus quadristamineus, 100 m, LHI 347, No 8, 24.i.1979, T. Kingston.

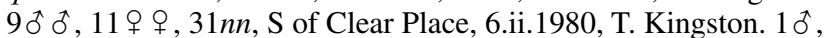
Mt. Gower, leaf litter, 100 m, no date, T. Kingston. 1 ․ Mt. Gower, 350 m, ii.1979, T. Kingston. 10 , 1 ㅇ, Lord Howe Island Stations: 007-0037, no date, T. Kingston. 1 , Erskine Valley, leaf litter, no date, T. Kingston. 10 , Erskine Valley, 175 m, leaf litter, Drypetes deplanchei, Cryptocarya triplinervis, LHI 454, No 8, 1.viii. T. Kingston. 40 oे, 1 우, 10nn, Broken Banyan Apartments, leaf litter, 7.x.1994, D.S.Horning and D.Horning. 3 ㅇ 9 , Lord Howe Island, no date, D. Horning. $1 \delta^{\widehat{ }}$, Smoking Tree Ridge summit, Queensland Museum berlesate 130, volcanic soil, $150 \mathrm{~m}$, Pickard veg DaCt, sieved litter, 7.xi.1979, G.B. Monteith. $10^{\star}$, same locality, east face, Queensland Museum berlesate, 163, volcanic soil, Pickard veg CfLq, sieved litter, 23.xi.1979, G.B. Monteith. $2 \delta^{\star} \sigma^{\star}$, Gully at Catalina crash, Queensland Museum berlesate 169, volcanic soil, 20 m, Pickard veg Hb, sieved litter, 25.xi.1979, G.B. Monteith. 1 ô, 1 , Lagoon Road, opposite museum, Queensland Museum berlesate 122, alluvial soil, Pickard veg DaCt, sieved litter, 5.

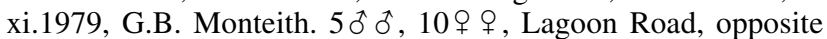
hospital, Queensland Museum berlesate 119, alluvial soil, $2 \mathrm{~m}$, Pickard veg DaCt, sieved litter, 4.xi.1979, G.B. Monteith. 1 ơ, 1 \% , Malabar summit, Queensland Museum berlesate, 168, volcanic soil, 200 m, Pickard veg DaCt, sieved litter, 25.xi.1979, G.B. Monteith. 19, Boat Harbour, Queensland Museum berlesate 161, $10 \mathrm{~m}$, volcanic soil, Pickard veg CfLq, sieved litter, 23.xi.1979, G.B. Monteith. 10ิ, Mount Eliza summit, Queensland Museum berlesate 154, volcanic soil, $150 \mathrm{~m}$, Pickard veg MnCa, sieved litter, 19.xi.1979, G.B. Monteith. 1 ${ }^{\star}$, Dawsons Point Ridge summit, 150 m, Queensland Museum berlesate 120, Pickard veg DaCt, sieved litter, 5.xi.1979, G.B. Monteith. 10 , Little Slope, 50 m, leaf litter, Howea forsteriana, LHI 355 No. 8, 22.xi.1979. T. Kingston. 4 0 o, 5 우, Behind Leanda Lei, Queensland Museum berlesate 127, calcareous soil, Pickard veg Hf, sieved litter, 6.xi.1979, G.B. Monteith.

Specimens collected by other than G.B.Monteith are in the Australian Museum; specimens collected by G.B.Monteith are deposited in the Queensland Museum.

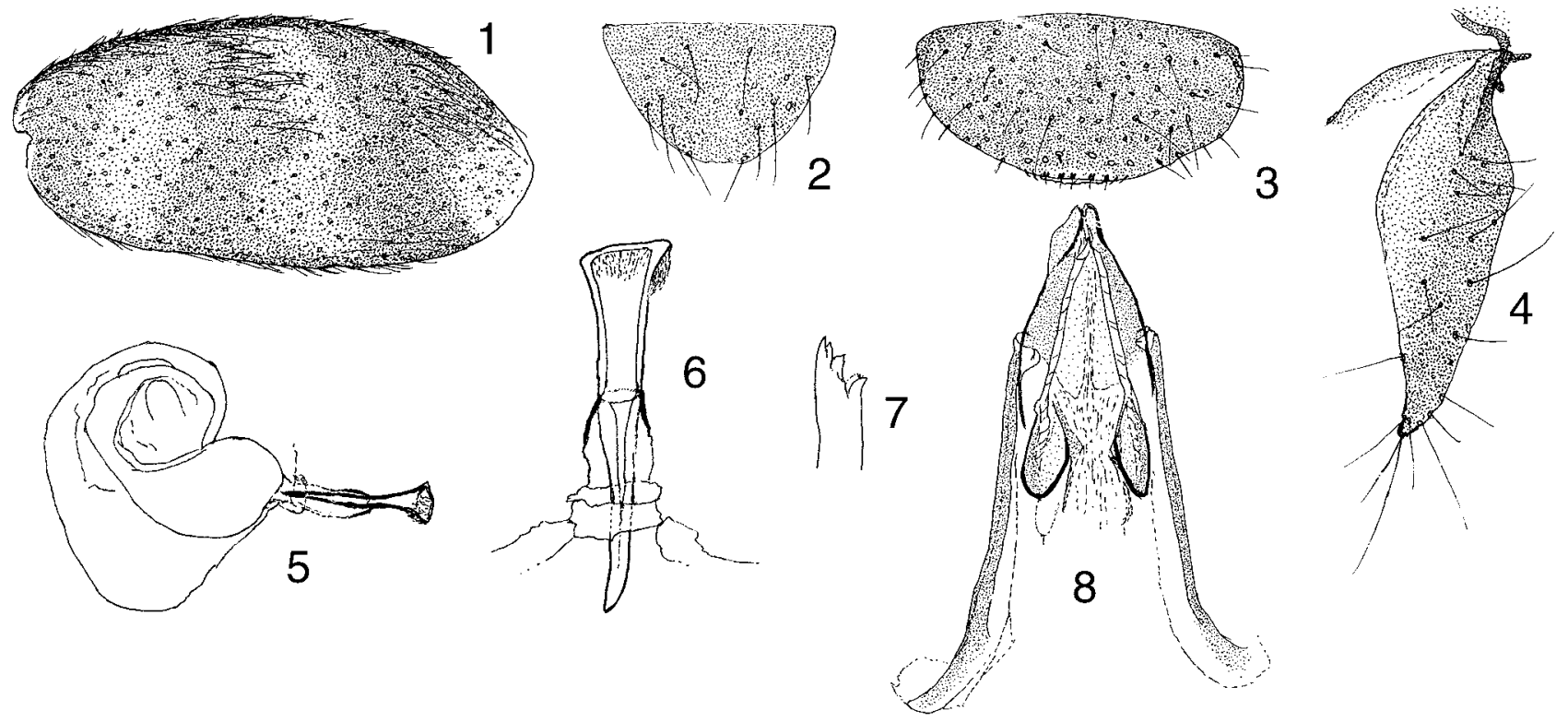

Figs 1-8. Lepolepis trifasciata n.sp. Female: (1) fore wing; (2) epiproct; (3) labrum; (4) gonapophyses; (5) structure associated with spermatheca; (6) same, enlarged; (7) lacinia. Male: (8) phallosome. 


\section{Description}

Female. Coloration (in alcohol). This species exhibits extreme variation in depth of colour, ranging from pale testaceous to specimens which are almost black. The variation may be age-related; nymphs are very pale. Parts are consistently relatively darker than one another through the series of specimens. Vertex, postclypeus, labrum and maxillary palps a little darker than the frons, genae darkest. Antennae very pale to dark brown. Eyes black. Thoracic nota variable, pleura darker. Legs variable with tarsi always paler than other segments. Fore wings (Fig. 1) pale with basal, middle and preapical irregular brown bands, the colour varies in depth to similar degree as other parts of the body of the same specimen. Abdomen dorsally pale in basal half, where it is covered by the reduced wings, distally darker where it is exposed. Terminal structures dark.

Morphology. Brachypterous. Length of body: $2.0 \mathrm{~mm}$. Median epicranial suture distinct, anterior arms very short, evanescent near origin. Vertex sharp. Postclypeus very slightly bulging. Head strongly pubescent, genal setae especially long and stout. Top of eyes about level with vertex. IO/D: 2.3; PO: 0.8. Ocelli absent. Labrum (Fig. 3) with five distal inner labral sensilla. Lacinia (Fig. 7). Measurements of hind leg: F: $0.62 \mathrm{~mm}$; T: $0.73 \mathrm{~mm}$; t1: $0.29 \mathrm{~mm}$; t2: 0.07 $\mathrm{mm}$; t3: $0.06 \mathrm{~mm}$; rt: 4.1:1:0.85. No ctenidiobothria. Fore wing length: $1.2 \mathrm{~mm}$; width: $0.5 \mathrm{~mm}$. Fore wing (Fig. 1) somewhat elytriform, veinless. Costal and hind margins with thickened band in basal half of wing. Wing surface with vestiture of very narrow scale-like setae as well as fairly dense cover of well-developed, erect, setae (nearly all lost in preservative). Wings reach to about three quarters of length of the abdomen. Hind wings reduced to a small, membranous, flap. Epiproct (Fig. 2) simple, rounded behind, sparsely setose. Paraproct simple, two trichobothria with ornamented alveoli and a few setae in distal half. Posterior spine slightly downwardly curved. Subgenital plate simple, wider than long, sparsely setose. Gonapophyses (Fig. 4). Spermathecal sac membranous, apparently without dentate sclerotic ring and without maculae. Associated with the sac is a large, strongly sclerotized, partly hollow, peg-like structure (Fig. 5, Fig. 6 [enlarged]). The structure is pointed at one end, widened at the other and hollow almost to the pointed end. The wider end of the funnel thus formed is open along one side. The peg-like structure appears to arise in and be an integral part of the otherwise thin, membranous wall of the sac. It lies in an outwardly-directed tube-like extension of the wall the mouth of which is firmly attached to the peg about half way along it so that part of the peg appears to be inside and part outside the sac tube. There are folds at the base of the tube which suggest that the peg is capable of being moved inwards and outwards along the lumen of the tube whilst being attached to its inner wall. The structure is seen in various positions through the abdominal wall, depending on the position occupied by the spermathecal sac and is possibly equivalent to the sheath of the spermathecal duct opening of Mockford (Mockford, 2005). It is large enough to be seen as a sclerotized, peg-like rod in the undissected abdomen.
Male. Coloration (in alcohol). As in female, equally variable.

Morphology. General morphology as in female. Length of body $2.2 \mathrm{~mm}$. IO/D: 2.4 ; PO: 0.86 . Fore wing length: $0.98 \mathrm{~mm}$; width: $0.46 \mathrm{~mm}$. Measurements of hind leg: $\mathrm{F}$ : $0.60 \mathrm{~mm}$.; T: $0.68 \mathrm{~mm}$; t1: $0.29 \mathrm{~mm}$; t2: $0.07 \mathrm{~mm}$; t3: 0.06; rt: 4.1:1:0.85. Ctenidiobothria absent. Epiproct as in female, simple, rounded behind, sparsely setose. Paraproct simple, two trichobothria with ornamented alveoli and a few setae in distal half. Hypandrium simple, rounded behind, setose. Phallosome (Fig. 8).

\section{Discussion}

There are now seven species described in the genus Lepolepis Enderlein: L. bicolor Broadhead (England (on introduced ground nuts from Africa), Ile Glorieuse, Réunion, India), $L$. ceylonica Enderlein (Sri Lanka, Taiwan), L. columbiensis Badonnel (Colombia), L. graemei Smithers (Norfolk Is.), L. pateriformis New (Aldabra), L. picta Thornton (Hawaii), and L. trifasciata (Lord Howe Island). The wings of $L$. graemei and L. trifasciata are longer than in the other species. When $L$. graemei was described no mention was made of the conspicuous peg-like structure associated with the spermatheca and reexamination of the dissection of the genitalia of a female paratype did not reveal any such organ. Having found the organ in the obviously similar $L$. trifasciata I reexamined further material of $L$. graemei and found that an almost identical structure was, in fact, present. The spermathecal sac in this genus is very delicate, was probably damaged and the peg-like structure lost when the earlier paratype was dissected. The peg-like structure is not easily homologized with part of the reproductive organs of any other female psocopterans but, as mentioned above, there is a possibility of it being homologous to the sheath of the spermathecal duct opening of Mockford (Mockford, 2005). The spermatheca has not been described for all species of Lepolepis but $L$. graemei and L. trifasciata share several significant features with each other which they do not share with other members of the genus for which the spermatheca has been described, such as a lesser degree of wing reduction, similarities in wing pattern, the presence of the peg-like structure associated with the spermatheca and the lack of spermathecal maculae, which are present in some of the other species. This suggests that the two species are closely related and stand apart from the others of which the spermatheca has been described. Given that the presence of the peglike structure is very likely a shared apomorphy it may be reasonable to erect a new genus for their accommodation. I hesitate to do this until further information is available on the nature of the spermatheca in those species for which it has not yet been described.

Etymology. The specific name refers to the three broad transverse dark bands across the wings.

Distribution. Known only from Lord Howe Island. 


\section{TROGIIDAE}

\section{Cerobasis annulata (Hagen)}

Clothilla annulata Hagen, 1865. Ent. mon. Mag. 2: 122.

Atropos annulata (Hagen). Kolbe, 1880. Jber. westf. Prov.Ver. Wiss. Kunst. 8: 135.

Myopsocnema annulata (Hagen). Enderlein, 1905. Jagersk. Exped. 18: 17.

Cerobasis annulata (Hagen). Badonnel, 1955. Pub. cult. Comp. Diam. Angola 26: 32.

Zlinia multispinosa Obr, 1948. Pub. Fac. Sci. Univ. Masaryk 306: 93, 104.

Cerobasis multispinosa (Obr.). Badonnel, 1955. Pub. cult. Comp. Diam. Angola 26: 32

Cerobasis bundyi Turner, 1977. J. nat. Hist. 11: 283.

Material studied. 19 , Mount Gower, litter, $850 \mathrm{~m}$, mossy forest, 27.ix.1978, T. Kingston. 1 \% , Erskine Valley, 175 m, litter, Drypetes, Cryptocarya, 12.viii.1979, T. Kingston.

Distribution. First record for Lord Howe Island. Previously known from Europe, North America, Australia (in stored products), St Helena, Robinson Crusoe Island, Hawaii, Azores, Morocco, Madeira. In the wild and in domestic situations.

\section{Cerobasis guestfalica (Kolbe)}

Hyperetes guestfalicus Kolbe, 1880. Jber. westf. Prov.Ver. Wiss. Kunst. 8: 132.

Hyperetes pinicola Kolbe, 1881. Ent. Nachr. 7: 255.

Cerobasis muraria Kolbe, 1882. Ent. Nachr. 8: 212.

Tichobia alternans Kolbe, 1882. Ent. Nachr. 8: 212.

Hyperetes tessulatus Hagen, 1883. Stettin. ent. Z. 44: 316.

Albardia alternans (Kolbe). Jacobson \& Bianchi, 1904. Orthop. Pseudoneuropt Russ. Reich p. 496.

Cerobasis guestfalica (Kolbe). Roesler, 1943. Stettin. ent. Z. 104: 13.

Material studied. 19 , near airport terminal. 15-26.ii.2001, M.S. Moulds. 1 \& , North Bay, 5 m, litter, Howea forsteriana, 15.xi.1978, T. Kingston.

Distribution. First record for Lord Howe Island. Previously known from North America, Europe, Canary Is., Azores, Israel, Saudi Arabia, Sardinia, Morocco, Tunisia, Japan, Mexico, Java, Australia, Norfolk Is., New Zealand, Hawaii, Bermuda, Kenya, South Africa, Robinson Crusoe Is., Argentina, Brazil, Chile, St. Helena, St. Paul Is., Jamaica, Kermadecs, Mauritius. In the wild and in domestic situations.

\section{Lepinotus inquilinus v. Heyden}

Lepinotus inquilinus Heyden, 1850. Stettin ent. Z. 11: 84.

Paradoxides psocoides Motschulsky, 1851. Bull. Soc. Imp. Nat. Moscou 24(2): 510.

Paradoxenus psocoides (Motschulsky). Motschulsky, 1852. Etudes entomologiques de 1852 p. 19.

Clothilla inquilina (Heyden). Brauer \& Löw, 1857.

Neuroptera austriaca. Wien. p. 32.

Clothilla picea Hagen, 1861. Smithsonian miscellaneous collections 4: 8.

Synonymy: Enderlein, 1905. Res. Swedish Exp. Egypt and White Nile p. 25.

Atropos inquilina (Heyden). Kolbe, 1880. Jber. westf. Prov.Ver. Wiss. Kunst. 8: 132.

Atropos sericea Kolbe, 1883b. Stettin. ent. Z. 44: 86.
Lepinotus piceus (Hagen). Hagen, 1883. Stettin. ent. Z. 44: 314. Atropos distincta Kolbe, 1888. Jaresb. Ver. f. Naturk. Zwickau 1887: 190, 191.

Atropos picea (Hagen). Kolbe, 1888. Jaresb. Ver.f. Naturk. Zwickau 1887: 190, 191.

Clothilla distincta (Kolbe). Tetens, 1891. Ent. Nachr. 17: 372.

Lepinotus sericeus (Kolbe). Tetens, 1891. Ent. Nachr. 17: 373, 384.

Cuixa canaria Navas, 1927. Bol. Soc. ent. ital. 59: 151.

Synonymy: Broadhead, 1949. Ent. mon. Mag. 85: 80.

Material studied. $6 \widehat{\delta} \widehat{\delta}, 8 \% \circ$, Mt. Gower, $850 \mathrm{~m}$, leaf litter, mossy forest, 2.ii.1979, T. Kingston. 4 के $\mathrm{b}^{t}$, 9 우 오, Intermediate Hill, $100 \mathrm{~m}$, leaf litter, Chionanthus quadristamineus, Cleistocalyx fullagarii, 24.i.1979, T.

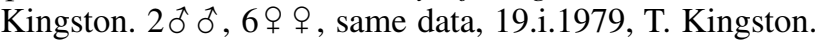
10 , Old Settlement, $80 \mathrm{~m}$, leaf litter, Drypetes deplanchei, Cryptocarya triplinervis, 18.iv.1979, T. Kingston. 2 के ô, $3 ㅇ$ ㅇ, Little Slope, $50 \mathrm{~m}$, leaf litter, Howea forsteriana, 7.i.1979, T. Kingston. same data, 20.xii.1979, T. Kingston. $2 ㅇ ․$. Big Slope, $20 \mathrm{~m}$, leaf litter, Howea forsteriana, 28.iii.1979, T. Kingston. 1 , Stevens Reserve, $5 \mathrm{~m}$, leaf litter, Howea forsteriana, 30.ix.1978, T. Kingston. 1 웅, North Bay, 5 m, leaf litter, Howea forsteriana, 15.xi.1979, T. Kingston. 10 , North End Big Pocket, Mt. Gower, ex leaf litter, Hedyscepe canterburyana, Dysoxylum pachyphyllum, 26.iv.2002, I. Hutton. 19, Little Island, below Far Flats, 10.viii.2001, I. Hutton. 10, Malabar Hill track, half way to Kims Lookout, 10.viii.2001, I. Hutton.

Distribution. First record for Lord Howe Island. The large number of previously published records indicate an almost cosmopolitan distribution for this species which is found indoors and in the wild.

\section{PSOQUILLIDAE}

\section{Rhyopsocidus niger (Smithers)}

Trogium nigrum Smithers, 1995. Gen. appl. Ent. 26: 2.

Rhyopsocidus niger (Smithers). Smithers and Mockford, 2004. Ent. mon. Mag. 140: 314.

Material studied. 19 , just behind beach at Old Gulch on western footslopes, narrow sclerophyll closed scrub, Melaleuca, leaf litter, 20.xi.2000, LHIS. 10ิ, on Boat Harbour walking trail, c. $200 \mathrm{~m}$ before harbour, broad megaphyllous closed sclerophyll forest, Pandanus, pitfall trap, 26.xi-3.xii.2000, LHIS. $1 \delta^{*}$ (much damaged specimen), Stephens Reserve, New Settlement, Howea forsteriana, beating, 9.xii.2000, G. Cassis.

Distribution. Recorded only from Lord Howe Island (as Trogium nigrum Smithers). 


\section{PSYLLIPSOCIDAE}

\section{Psocathropos lachlani Ribaga}

Psocathropos lachlani Ribaga, 1899. Riv. Pat. Veg. 8: 157. Psocinella slossonae Banks, 1900. Entom. News 11: 432. Synonymy: Gurney, 1949. J. Acad. Wash. Acad. Sci. 39: 63. Axinopsocus microps Enderlein, 1903. Zool. Jb. Abt. Syst. 19: 3. Synonymy: Lienhard \& Halperin, 1988. Israel J. Ent. 22: 15. Psoquilla microps (Enderlein). Enderlein, 1908. Zool. Anz 33: 782. Vulturops floridensis Corbett \& Hargreaves, 1915. Psyche 22: 142. Synonymy: Mockford, 1993. North American Psocoptera. Gainesville. p. 51.

Psocatropos [sic] lesnei Badonnel, 1931. Ann. sci. nat., Zool. (10)14(16): 254.

Psocathropos microps (Enderlein). Badonnel, 1932. Bull. Soc. zool. Fr. 57: 117.

Synonymy: Badonnel, 1944. Rev. franc. Ent. 11: 59.

Material studied. $10 \hat{\sigma}, 5 q q$, Mt. Gower, $850 \mathrm{~m}$, leaf litter, mossy forest, 2.ii.1979, T. Kingston. 1 specimen, Little Slope, leaf litter, Howea forsteriana, 7.i.1979, T.

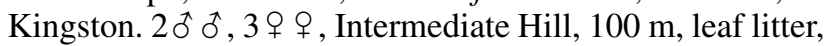
Cleistocalyx fullagarii, Chionanthus quadristamineus, 19.i.1979, T. Kingston. 1 specimen, Big Slope, 20 m, leaf litter, Howea forsteriana, 28.iii.1979, T. Kingston.

Distribution. First record for Lord Howe Island. Also known from Australia, Europe, Morocco, North America, Cuba, Jamaica, Nicaragua, Mozambique, Angola, Congo, Nigeria, Madeira, Madagascar, Réunion, Thailand, Taiwan, Hawaii. Found in the wild and in domestic situations.

\section{CAECILIUSIDAE}

\section{Stenocaecilius quercus (Edwards)}

Caecilius quercus Edwards, 1950. Pap. Proc. R. Soc. Tasm. (1949): 131.

Stenocaecilius quercus (Edwards). Mockford, 2000. Trans. Amer. ent. Soc. 125(4): 357.

Material studied. $4 \hat{\delta} \hat{\delta}, 3 ㅇ$, Mt Gower summit; ridge between creeks 2 (middle) and 1 (most easterly), Hedyscepe canterburyana, Zygogynum howeanum, Cryptocarya gregsonii, leaf litter, 25.vi.2001, Ian Hutton. 1\%, Muttonbird Point booby colony area, under native grass, Poa poiformis, leaf litter, 22.vi.2001, Ian Hutton. $10^{\star}, 19$, Track to Malabar Hill, $50 \mathrm{~m}$ N summit, ex leaf litter, 10.viii.2001, I. Hutton. 10, Malabar Hill, on path to Kims Lookout, narrow sclerophyll closed scrub, Dodonaea/Cassinia, leaf litter, 24.xi.2000, LHIS. $2 \hat{\delta}$, c. $25 \mathrm{~m}$ above coastal trail to Boat Harbour, $750 \mathrm{~m}$ from start, close rain forest, Drypetes/Cryptocarya, Baloghia inophylla. beating, 26.xi.2000, P. Flemons, J. Tarnawski. $10^{\star}$, eastern slope of Dawsons Point, ridge near top, closed rain forest, Cleistocalyx/Chionanthus, leaf litter, 24.xi.2000, LHIS. 19 , junction of Kims Lookout trail and North Beach trail, closed rain forest, Drypetes/Cryptocarya, Olea paniculata, beating, 25.xi.2000, L. Wilkie, H. Smith. 10 , junction of Kims Lookout trail and North Beach trail, closed rain forest, Drypetes/Cryptocarya, Olea paniculata, beating, 25.xi.2000, L. Wilkie, H. Smith. $20 \hat{0}, 2$ 우, eastern aspect of Transit Hill near summit, narrow closed sclerophyll scrub, Melaleuca/Cassinia, leaf litter, 19.xi.2000,
LHIS. 10, Mt Lidgbird SE end in dip between Pimple and main cliff. 21.v.2001, leaf litter caught in Birds Nest Fern, Asplenium goudeyi, $1.5 \mathrm{~m}$ off ground. Ian Hutton. $1 \mathrm{o}^{\hat{\mathrm{C}}} \mathrm{Mt}$ Gower $\mathrm{N}$ face, following cliff base along from Eddies Cave, on ridge between gullies 1 and 2, 26.v.2001, Metrosideros nervulosa, Dysoxylon pachyphyllum, Cleistocalyx fullagarii, leaf litter, Ian Hutton. $20 \hat{\sigma}, 2 q \phi$, Muttonbird Point Booby colony area, 22.vi.2001, litter underneath Kikuyu grass, Ian Hutton. $10^{\widehat{t}}$, Little Slope, broad-leafed herb vegetation, mixed ferns/herbs, leaf litter, 7.xii.2000, LHIS. 1 \%, c. $50 \mathrm{~m}$ $\mathrm{S}$ of summit of Mt. Eliza on western face, orthophyll short grass, Poa, leaf litter, 20.xi.2000, LHIS. $2 \delta^{\star} \delta^{\star}$, Mt Gower $\mathrm{N}$ face, base of waterfall, off summit (east one), 26.v.2001, Boehmeria calophleba, Machaerina insularis, Elatostema grande, Blechnum howeanum, Blechnum geniculatum leaf litter, Ian Hutton. 10 ${ }^{\hat{}}$, eastern slope of Dawsons Point Ridge above Old Settlement, closed rain forest, Drypetes/ Cryptocarya (exposed), leaf litter, 1.xii.2000, LHIS. 20 ô, just behind beach at Old Gulch on western footslopes, narrow sclerophyll closed scrub, Melaleuca, leaf litter, 20.xi.2000, LHIS. 10 , eastern end of Boat Harbour beach, narrow closed sclerophyll scrub, Melaleuca/Cassinia, Drypetes deplanchei, beating, 26.xi.2000, P. Flemons, J. Tarnawski. $1 \delta^{t}$, in forest behind Research Station, palm and banyan litter, 22.ii.2001, J. Tarnawski. 10, Get Up Place, trail to Mt. Gower, broad closed sclerophyll scrub, Dracophyllum/Metrosideros, leaf litter, 2.xii.2000, LHIS. $2 \widehat{\widehat{t}}$, southern end of Old Settlement Beach, sweep sampling, 7.xii.2000, G. Cassis. 10 , eastern slope of Dawsons Point Ridge near top, closed rain forest, Cleistocalyx/Chionanthus, 1-4.xii.2001, C. Reid. 1 , Goat House walking track, c. $550 \mathrm{~m}$ from junction with Erskine Valley track, Intermediate Hill, Cryptocarya triplinervis, hand collected, 6.xii.2000, G. Cassis. 1 \% , bottom of track from Capella to Boat Harbour, 15.xii.2000. 10 , Mt Lidgbird, SE ridge leading to Pimple, $20 \mathrm{~m}$ down track SE of Pimple summit, 23.v.2001, Alyxia squamulosa, Coprosma huttoniana, Xylosma parvifolium leaf litter, Ian Hutton. $2 q q$, c. $50 \mathrm{~m} \mathrm{~S}$ of summit of Mt. Eliza on western face, orthophyll short grass, Poa, Drypetes deplanchei, beating, 1.xii.2000, H. Smith. $10^{\star}$, junction of Kims Lookout trail and North Beach trail, closed rain forest, Drypetes/ Cryptocarya, Pouteria myrsinoides, beating, 25.xi.2000, L. Wilkie, H. Smith. 10, eastern slope of Dawsons Point Ridge near top, closed rain forest, Cleistocalyx/Chionanthus, 1-4.xii.2001, C. Reid. $2 \delta^{\dagger}$, 1 ㅇ, Rocky Run Creek, leaf litter, Cleistocalyx fullagarii, Pandanus forsteri, Coprosma putida, 18.v.2002, I. Hutton. 10, Mt. Lidgbird, W side valley, between Pimple and summit, litter, Hedyscepe canterburyana, Macropiper hooglandii, Coprosma huttoniana, 11.iv.2002, I Hutton. 10, Rocky Run Creek, Intermediate Hill crossing, litter, Cleistocalyx fullagarii, Drypetes deplanchei, 18.v.2002, I. Hutton. 10े, $10 \mathrm{~m} \mathrm{NW}$ Malabar Hill track in forest at beginning, leaf litter, Drypetes deplanchei, Pouteria myrsinoides, Xylosma maidenii, Alyxia ruscifolia, 10.viii.2001, I. Hutton. 10, Creek gully behind Lord Howe Island Board Office, litter, Howea forsteriana, Drypetes deplanchei, Cryptocarya triplinervis, 9.viii. 2001, I. Hutton. 10 , Mount Gower, north face, near creek crossing of track, litter, Chionanthus quadristamineus, Guioa coriacea, Drypetes deplanchei, 19.v.2002, I. Hutton.

Distribution. Previously recorded from Lord Howe Island, Tasmania and Australia. 


\section{Paracaecilius lemuris Smithers}

Paracaecilius lemuris Smithers, 1994b. Rec. Aust. Mus. 46: 126.

Material studied. 19 , junction of Kims Lookout trail and North Beach trail, closed rain forest, Drypetes/Cryptocarya, Pouteria myrsinoides, beating, 25.xi.2000, L. Wilkie, H. Smith. $10^{\text {t }}$, southern face of Mt. Lidgbird, at base of summit tabletop, closed rain forest, Drypetes/Cryptocarya (calcarenite), Chionanthus quadristamineus, beating, 26.xi.2000, P. Flemons, J. Tarnawski. 10 , west of walking trail to Mt. Gower, at base of Scaly Bark Ridge, closed rain forest, Cleistocalyx/Chionanthus, beating, 25.xi.2000, M. Elliott, N. Plunkett-Cole. 1 \% , eastern face of Mt. Lidgbird, closed rain forest, Cryptocarya gregsonii, Zygogynum howeanum, beating, 26.xi.2000. M. Elliott, N. PlunkettCole. 19 , junction of Kims Lookout trail and North Beach trail, closed rain forest, Drypetes/Cryptocarya, Baloghia inophylla, beating, 25.xi.2000, L. Wilkie, H. Smith. 10 , southern face of Mt. Lidgbird, at base of summit tabletop, closed rain forest, Drypetes/Cryptocarya (calcarenite), Arthropteris tenella, beating, 26.xi.2000, P. Flemons, J. Tarnawski. 19 , Little Slope, broad megaphyllous closed sclerophyll forest, leaf litter, 30.xi.2000, LHIS. $2 \hat{0} \widehat{0}, 4$ 우, southern face of Mt. Lidgbird, at base of summit tabletop, closed rain forest, Drypetes/Cryptocarya (calcarenite), Zygogynum howeanum, beating, 26.xi.2000, P. Flemons, J. Tarnawski. 10 , walking trail through Erskine Valley, closed rain forest, Cleistocalyx/Chionanthus, Xylosma maidenii, beating, 25.xi.2000, P. Flemons, J. Tarnawski. $2 \widehat{\widehat{\partial}} \hat{\mathrm{o}}$, eastern slope of Dawsons Point Ridge near top, closed rain forest, Cleistocalyx/Chionanthus, Drypetes deplanchei, beating, 1.xii.2000, C. Reid, H. Smith. 1 \% , Research Station backyard, surrounded by Drypetes/Cryptocarya, closed rain forest. $1 \delta, 1 \%$, eastern slope of Dawsons Point Ridge near top, closed rain forest, Cleistocalyx/Chionanthus, 4-8.xii.2001, C. Reid. 10, Little Island, below Far Flats, ex litter, Howea forsteriana, 10.viii.2001. I. Hutton. 19 , Run Creek, Intermediate Hill track crossing, litter, Pandanus forsteri, Cleistocalyx fullagarii, Coprosma putida, 18.v.2002, I. Hutton.

Distribution. First record for Lord Howe Island. Previously recorded from Australia.

\section{Valenzuela pteridii (Smithers)}

Caecilius pteridii Smithers, 1977. Rec. Aust. Mus. 31: 257. Valenzuela pteridii (Smithers). Mockford, 2000. Trans. Amer. ent. Soc. 125(4): 353.

Material studied. 19 , Rocky Run Creek, where Intermediate Hill track crosses, litter, Cleistocalyx fullagarii, Pandanus forsteri, Coprosma huttoniana, 18.v.2002, I. Hutton.

Distribution. First record for Lord Howe Island. Previously recorded from the Australia and Tasmania (as Caecilius pteridii).

\section{ECTOPSOCIDAE}

\section{Ectopsocus petersi Smithers}

Ectopsocus punctatus Thornton \& Wong, 1968. Pacific Ins. Monogr. 19: 137 ( đ)

Ectopsocus petersi Smithers, 1978. Irish Nat. J. 19(5): 144.

Ectopsocus australis Schmidt \& Thornton, 1993. Mem. Mus. Vict. 53(2)(1992): 162.

Synonymy: Smithers, 2003. Ent. mon. Mag. 139: 5.

Material studied. $2 q q$, Malabar Hill, on path to Kims Lookout, narrow sclerophyll closed scrub, Dodonaea/ Cassinia, Dodonaea viscosa, beating, 24.xi.2000, L. Wilkie, G. Carter. 19 , Stephens Reserve, New Settlement, megaphyllous broad sclerophyll forest, Howea spp., M.S. Moulds. 10 , Mt Gower summit, ridge between creeks 2 (middle) and 1 (most easterly), Hedyscepe canterburyana, Zygogynum howeanum, Cyptocarya gregsonii, leaf litter, 25.vi.2001, Ian Hutton. 10ิ, Stephens Reserve, New Settlement, megaphyllous broad sclerophyll forest, Howea spp., Drypetes deplanchei, beating, 13.xii.2000, R. Harris. 10 , 1 \% , corner Lagoon Rd. and Middle Bay Rd., 15-26.ii.2001, M.S. Moulds. 1 ㅇ, Lagoon Beach, rubbish tip/airstrip, beating, Ochrosia elliptica, 27.xi.2000, M. Elliott and N. Plunkett-Cole. $1 \%$, walking trail through Erskine Valley, closed rain forest, Cleistocalyx/Chionanthus, leaf litter, 2.xii.2000, LHIS. 1 \% , Lagoon Beach, between rubbish tip and airstrip, ex Ochrosia elliptica, beating, 27.xi.2000, M. Elliott, N. Plunkett-Cole. 1 \& , Little slope, $50 \mathrm{~m}$, leaf litter, Howea forsteriana, 7.i.1979, T. Kingston. 19 , Transit Hill summit, Berlesate No 153, Pickard Veg DaCt, sieved litter, 18.xi.1979, G.B. Monteith. 3 q $q$, North Bay, scrub, pyrethrum knockdown, 19.xi.1979, G.B. Monteith.

Distribution. Previously recorded from Lord Howe Island (as Ectopsocus punctatus Thornton and Wong). Also recorded from Great Britain, Europe, North America (introduced?), Egypt, Australia, New Zealand. Common on dead leaves.

\section{Ectopsocus insularis Smithers \& Thornton}

Ectopsocus insularis Smithers \& Thornton, 1974a. Rec. Aust. Mus. 29(8): 221

Material studied. $2 \hat{\delta} \widehat{\delta}$, Mount Lidgbird, east side of valley between Pimple and summit, ex litter, Cryptocarya gregsonii, Hedyscepe canterburyana, 11.iv.2002, I. Hutton.

Distribution. First record for Lord Howe Island. Previously recorded from Norfolk Island. 


\section{PERIPSOCIDAE}

\section{Peripsocus milleri (Tillyard)}

Peripsocopsis milleri Tillyard, 1923. Trans. N. Z. Inst. 54: 195. Peripsocus reductus Badonnel, 1943. Faune de France 42: 98.

Peripsocus eucalypti Edwards, 1950. Pap. Proc. R. Soc. Tasm (1949): 122.

Peripsocus milleri (Tillyard). Smithers, 1967. Aust. Zool. 14: 70.

Peripsocus nitens Thornton \& Wong, 1968. Pacific Ins. Monogr. 19:

129. Synonymy: Smithers, 1994a. Aust. Entomol. 21: 7.

Synonymy: New, 1973. J. Aust. ent. Soc. 12: 346.

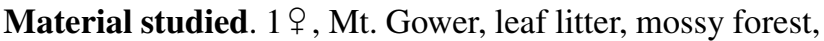
27.ix.1978, T. Kingston. $3 q \circ$, Transit Hill (Nicholls), 60 m, leaf litter, 26.x.1979, T. Kingston. 19 , North Bay, scrub, pyrethrum knockdown, 19.xi.1979, G.B. Monteith. 1 , Erskine Valley, rainforest, pyrethrum knockdown, 24.xi.1979, G.B. Monteith.

Distribution. First record from Lord Howe Island. Previously recorded from Tasmania, Australia, New Zealand, Auckland Island, Kermadecs, Norfolk Island, Hawaii, Europe, Canary Islands, Madeira, North America. It is also known to occur in New Caledonia (unpublished material in the Australian Museum). Corticolous.

\section{Peripsocus similis Enderlein}

Peripsocus similis Enderlein, 1903. Ann. hist.-nat. Mus. Hung. 1: 290.

[Not Peripsocus similis Badonnel, 1955. Pub. cult. Comp. Diam. Angola 26: 180].

Redescription of female: Thornton, 1959. Proc. R. ent. Soc. Lond. (B) $28: 37$

Material studied. $1 \uparrow$, Mt Lidgbird, SE corner above Pimple; ridge above last cliff leading to summit, Metrosideros nervulosa, Macropiper hooglandii, Hedyscepe canterburyana, Coprosma putida, leaf litter, 23.vi.2001, Ian Hutton.

Distribution. First record from Lord Howe Island. Previously recorded from Singapore, Hong Kong, Fiji, Tonga, Hawaii, Krakatau, Moorea, China.

\section{PSEUDOCAECILIIDAE}

\section{Howeanum huberi Smithers}

Howeanum huberi Smithers, 1995. Gen. Appl. Ent. 26: 5.

Material studied. $1 \delta$, western slope of Dawsons Point Ridge off North Beach Trail, closed rain forest, Drypetes/ Cryptocarya (calcarenite), Drypetes deplanchei, beating, 24.xi.2000, P. Flemons, J. Tarnawski. 1 \% , southern end Salmon Beach, vic. Little Island, Xylosoma maidenii, beating, 27.xi.2000, C. Reid, H. Smith. 2 ㅇ $q$, Mt. Gower summit, mossy forest, pyrethrum knockdown, 9.xi.1979, G.B. Monteith. 1 ㅇ, Big Creek, Mountain Inn, rainforest, pyrethrum knockdown, 11.xi.1979, G.B. Monteith.

Note. In the female from the southern end of Salmon Beach the tibiae are white and stand out in starker contrast to the very dark brown of the body and other parts of the legs than in the other specimens.

Distribution. Known only from Lord Howe Island.

\section{Mepleres fasciata (Smithers \& Thornton)}

Pseudoscottiella fasciata Smithers \& Thornton, 1975. Rec. Aust. Mus. 29: 459.

Meniscopsocus fasciatus (Smithers \& Thornton). Li Fasheng, 1993. Sci. Tech. Publ. House. Guandong Prov. China p. 382.

Mepleres fasciata (Smithers \& Thornton). Yoshizawa, 2000. Ent. Sci. 3(4): 674.

Material studied. $1 \hat{0}$, Little Slope, broad megaphyllous closed sclerophyll forest, Howea belmoreana, Howea forsteriana, beating, 30.xi.2000, P. Flemons, J. Tarnawski. 10 , Little Island, coastal track to Erskine Valley, palm leaf litter, 13.xii.2000, G. Cassis. 10, Stephens Reserve, New Settlement, megaphyllous broad sclerophyll forest, Howea spp., 15-26.ii.2001, M.S. Moulds. 10 , Mt Lidgbird, SE ridge leading to Pimple, $100 \mathrm{~m}$ down track SE of Pimple summit, Dracophyllum fitzgeraldii, Macropiper hooglandii, Metrosideros nervulosa, leaf litter, 23.v.2001, Ian Hutton.

Distribution. Known only from Lord Howe Island.

\section{Mepleres hollowayi (Smithers \& Thornton)}

Pseudoscottiella hollowayi Smithers \& Thornton, 1975. Rec. Aust. Mus. 29: 460.

Meniscopsocus hollowayi (Smithers \& Thornton). Li Fasheng, 1993. Sci. Tech. Publ. House. Guandong Prov. China p. 382.

Mepleres hollowayi (Smithers \& Thornton). Yoshizawa, 2000. Ent. Sci. 3(4): 674.

Material studied. 10 , Little Slope, broad-leafed herb vegetation, mixed ferns/herbs, Pennisetum clandestinum, beating, 30.xi.2000, P. Flemons, J. Tarnawski. $2 \hat{\widehat{o}} \widehat{0}$. Mt Gower summit; ridge between creeks 2 (middle) and 1 (most easterly), Hedyscepe canterburyana, Zygogynum howeanum, Cyptocarya gregsonii, leaf litter, 25.vi.2001, Ian Hutton. $1 \hat{\delta}^{\hat{d}}$, west end of Mt Gower summit on south edge, Metrosideros nervulosa, Zygogynum, Dracophyllum fitzgeraldii, Hedyscepe canterburyana, leaf litter, 15.v.2001,

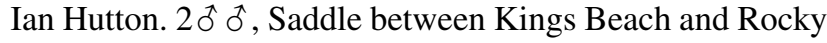
$\mathrm{Rd}, 20 \mathrm{~m}$ below on $\mathrm{E}$ side, grass/vine gap in rainforest, 4-8.ii.2001, C. Reid. 10ิ, Little Island, coastal track to Erskine Valley, palm leaf litter, 13.xii.2000, G. Cassis. 1 ô, $^{\hat{0}}$ 1 ㅇ, Transit Hill (Nicholls), 60 m, leaf litter, Cleistocalyx 
fullagarii, Chionanthus quadristamineus, 10.x.1978, T. Kingston. 10, Rocky Run Creek, where Intermediate Hill track crosses, litter, Metrosideros nervulosa, Pandanus forsteri, 18.v.2002, I Hutton.

Distribution. Known only from Lord Howe Island.

\section{Mauropsocus n.gen.}

Belonging to the Pseudocaeciliidae: Zelandopsocinae. Females micropterous. Tarsi 3-segmented. Claws with a minute denticle on one claw of each pair. Subgenital plate incipiently bilobed, each lobe with one large posteriorly directed seta near hind margin. Ventral valve and dorsal valve of gonapophyses with large, pointed apophysis. Setae on head, thorax and abdomen (other than genitalia) include many seated in large, raised alveoli and have distal ends truncate, expanded or extended on one side at the apex. No ocelli. Apical antennal segment distally narrow. Abdominal terga each with well sclerotized posterior transverse band and a more lightly sclerotized anterior band.

Type species: Mauropsocus monteithi $\mathrm{n} . \mathrm{sp}$.

Mauropsocus differs significantly from other genera of the subfamily in having many of the setae conspicuously modified. They arise from greatly exaggerated, raised alveoli and many have the apex of unusual form. The apex of some setae is simply truncate, in others it is distally expanded or the apex is modified so that one side of the apex is extended beyond the other (Figs 10-14). The modified setae are also much thicker than normal setae and in many the base is also modified, being narrowed, neck-like, at the attachment to the alveolus (Fig. 13). The male of M. monteithi is not known but on the basis of the female characters alone its nearest relatives appear to be Zelandopsocus, Austropsocus and Howeanum. Howeanum is known from two species, H. costale (Thornton and New) (Australian) and H. huberi Smithers (Lord Howe Island). The former is macropterous in both sexes and the latter is macropterous in the male and micropterous in the female.

\section{Mauropsocus monteithi n.sp.}

Material studied. 1 \& (HOLOTYPE), QM T99350, Big Creek, Mountain Inn, rainforest, pyrethrum knockdown, 11.xi.1979, G.B. Monteith. Holotype in the Queensland Museum.

Etymology. Mauros $=$ Gr. dark, referring to the dark colour of the species. This species is named for Dr Monteith in recognition of his immense contribution to Australian entomology.

Distribution. Known only from Lord Howe Island.
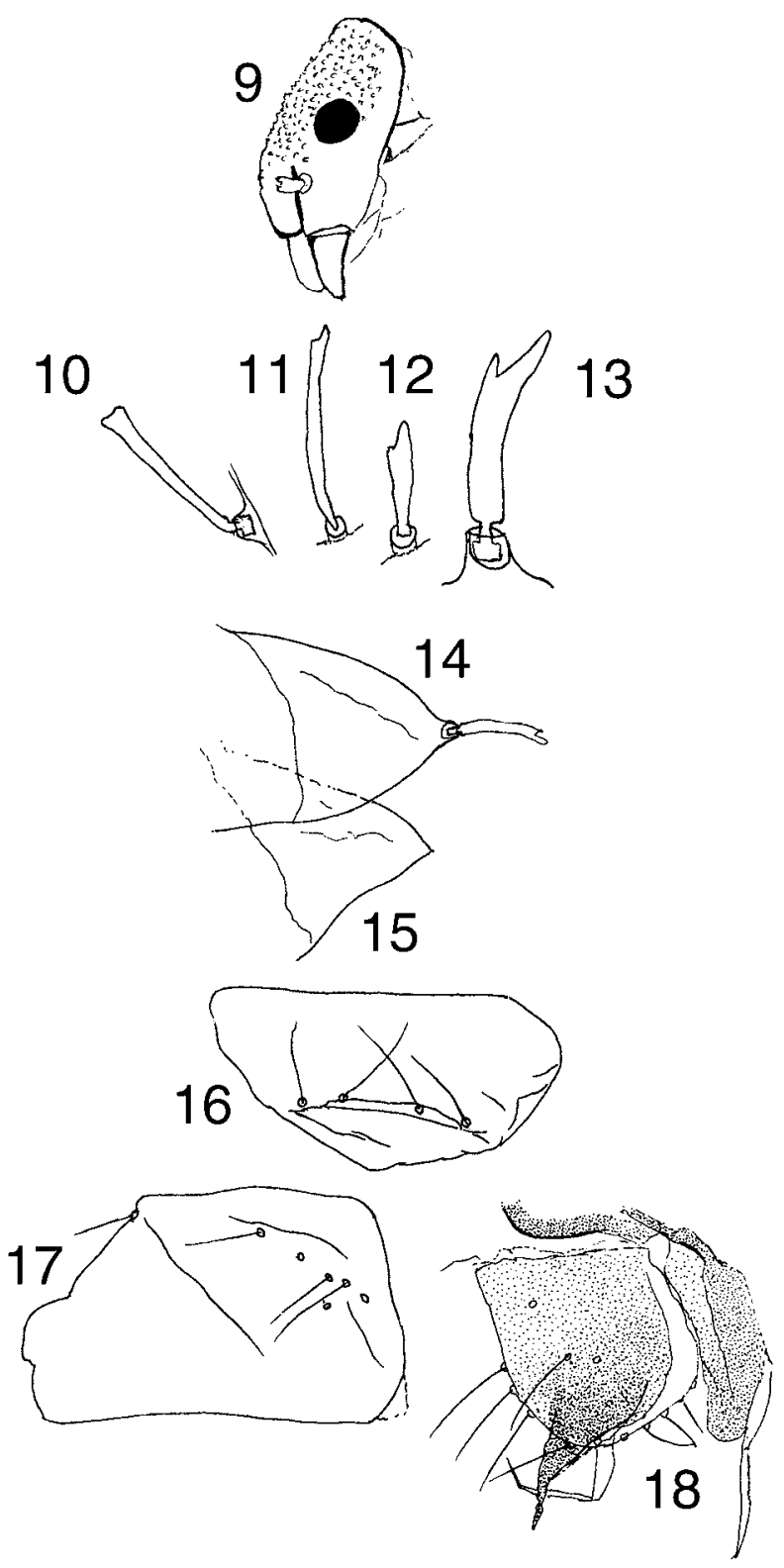

Figs 9-18. Mauropsocus monteithi n.gen. and n.sp. Female: (9) head, lateral (setae not shown); $(10,11,12)$ modified setae; $(13)$ large modified seta at wing apex; (14) fore wing; (15) hind wing; (16) epiproct; (17) paraproct; (18) gonapophyses.

\section{Description}

Female. Coloration (in alcohol). Head dark brown, a paler spot in middle of front of head, in position usually occupied by ocelli. A darker mark from eye to antenna base, lateral and anterior transverse margin of postclypeus very dark brown. Median epicranial suture almost black; anterior arms absent. Postclypeus with indistinct, irregular, almost transverse, slightly converging dark stripes. Labrum pale. Antennae brown. Eyes black. Maxillary palps brown. Prothorax dorsally dark. Meso- and metanotum each with 
dark brown transverse band across posterior part of tergum in which dark spots are arranged in irregular transverse rows, the spots being large alveoli from which arise strong setae. Anterior part of tergum paler. Legs dark brown except for distal half of hind tibia and tarsus, which are slightly paler. Abdominal terga banded in similar way to thoracic terga i.e each tergum darker in posterior part in than in anterior part. A fine, pale, median longitudinal line from front of mesonotum to hindmost abdominal tergum.

Morphology. Micropterous. Length of body: $1.7 \mathrm{~mm}$. Median epicranial suture very distinct, finer anteriorly, anterior arms absent. Head capsule with raised, enlarged alveoli giving most of head a rough appearance. Vertex narrow but rounded. Front of head flat. Frons poorly delimited because of lack of anterior arms of epicranial suture and posterior part of epistomial suture. Head from side (Fig. 9, setae not shown) short, postclypeus hardly protruding. Labrum without lateral styli on anterior margin. Five inner sensilla, two trichoid, three placoid. Genae glabrous, without enlarged alveoli, therefore having a smoother appearance than rest of head capsule. Antennae 13-segmented but short; apical segment strongly narrowed distally. Length of flagellar segments: f1: $0.055 \mathrm{~mm}$; f2: $0.045 \mathrm{~mm}$. Eyes very small, round, of about 20 spaced ommatidia, placed on side of head slightly nearer to base of antenna than vertex. No ocelli. Fourth segment of maxillary palp short, width two-thirds of length. Thoracic and abdominal terga each with sclerotized transverse band in posterior part giving the dorsal view of the insect its strongly banded appearance. Integument of each segment anterior to the sclerotized band less heavily sclerotized. More heavily sclerotized part of the terga bears rows of strongly developed, variously modified setae (Figs 10-12) each arising from an enlarged alveolus. Mesonotum with one posterior row of setae and two single setae representing an anterior row. Integument in heavily sclerotized posterior areas bears more or less evenly spaced tiny papillae. Abdominal terga as thoracic but surface papillae arranged roughly in transverse rows in some areas. Modified setae in two irregular rows, those of the posterior row on each segment larger than those of anterior row. Measurement of hind leg: F: $0.26 \mathrm{~mm}$.; T: $0.39 \mathrm{~mm}$; t 1 : $0.07 \mathrm{~mm}$.; t2: 0.02 mm.; t3: 0.04 mm.; rt: 3.5:1:2. No ctenidiobothria. Claws with one minute denticle on one claw of each pair. Outer side of femora sparsely setose, setae fine. Fore tibia bearing fine, normal setae overall, outer side with a row of a few larger, blunt-ended setae arising from larger raised alveoli. Mesotibia as front tibia but the row of setae on the outer side has expanded truncate tips. Metatibia as mesotibia but larger setae with expanded truncate apices in a row on the outer side arise from large alveoli. Pulvillus broad. No coxal organ. Fore wing (Fig. 14) reduced to a very small lobe with a single, very large, modified apical seta (Figs 13, 14). Hind wing (Fig. 15) smaller, simple, without seta. Epiproct (Fig. 16) a simple, lightly sclerotized lobe with a transverse ridge bearing a few long, fine setae. Paraproct (Fig. 17) lightly sclerotized, with a few setae. Subgenital plate (damaged in preparation) apparently incipiently bilobed behind with a large seta on each lobe. Gonapophyses (Fig. 18). Ventral and dorsal valves each with well-developed, long, fine, preapical apophysis.

Male. Unknown.

\section{Discussion}

Mockford (1984) reassessed and characterized the genera then included in the Philotarsidae and some of the genera in the Pseudocaeciliidae. As a result he made some redistribution of the genera between the families and erected the family Bryopsocidae (for Bryopsocus Thornton, Wong and Smithers) which he considered to be intermediate between the other two families.

Mauropsocus monteithi is clearly a micropterous pseudocaeciliid belonging to the subfamily Zelandopsocinae and it is appropriate to compare it with the five genera of the family which have 3-segmented tarsi, namely, Zelandopsocus Tillyard, Austropsocus Smithers, Novopsocus Thornton, Howeanum Smithers and Trimerocaecilius Meinander, although the last is not considered a member of the Zelandopsocinae and may not even be a true pseudocaeciliid (Lienhard, 1998).

\section{Pseudocaeciliidae n.gen. and n.sp.}

The collection includes two remarkable nymphs which cannot readily be associated with any adults so far collected from Lord Howe Island. They certainly represent an undescribed genus and species. The most likely family to which they belong is the Pseudocaeciliidae. As adults are not yet available this placing must be considered tentative.

Material studied. $1 n$, Southern end of Salmon Beach, vic. Little Island, Xylosoma maidenii, beating, 27.xi.2000, C. Reid, H. Smith. 1n, Stephens Reserve, New Settlement, Drypetes deplanchei, beating, 13.xii.2000, R. Harris. (Originally preserved on points these two specimens have been removed and are now stored in alcohol).

\section{Description}

Nymph. The following brief description is based mainly on the larger specimen.

Coloration. Head pale straw-coloured, with slightly darker, irregular, band adjacent to the inner margin of the compound eyes; a similar band on either side of the median 
epicranial suture from vertex to position usually occupied by the ocellar tubercle. Postclypeus, genae and labrum straw-coloured. Eyes colourless. Antennae coloured as head. Mesonotum mottled, irregularly straw-coloured; metanotum pale with a brownish spot on each side of midline. Legs colourless except for black claws. Abdominal tergites 4-6 brownish, other tergites pale.

Morphology. Antennal flagellar segments with welldeveloped, porect setae, many longer than segment diameter. Head almost circular in frontal view; front of head, including frons and postclypeus, strongly concave so that the front of the head appears hollowed out or bowl-shaped. When viewed from the side the head is very short, the anterior and posterior margins almost parallel to one another, the head as a whole thus somewhat discoid. Epistomial suture not obvious. Rim of bowl-shaped frontal depression and anterior margin of mesonotum with a row of large, forwardly-directed setae. Eyes situated very low on sides of head, their lower margin almost in contact with antennal socket. Upper margin of eyes well below level of the rounded vertex. Basal segment of abdomen with a transverse row of setae; long setae present laterally on either side of posterior end of abdomen.

Note. The very unusual shape of the head suggests that it is adapted for some biological activity unusual for a psocopteran. The circular outline of the head and the fact that it has an unusual arrangement of forwardly-directed setae (sensory?) suggests the possibility of phragmosis. This habit is confirmed for only one genus of wood-boring Psocoptera and suspected in another. Further observations on this species are needed to determine the function of the unusual head shape.

The larger of the two specimens (that from Salmon Beach) is in its final nymphal instar. This is indicated by two crescentic black marks on the front of the head in the position usually occupied by the ocellar tubercle in adults and the size of the wing buds, which extend to about half the length of the abdomen. The smaller specimen (from Stephens Reserve) is probably in the third instar, judging by the very short wing buds. The wing buds of the larger are brown. The sex of the larger specimen cannot be determined because the hind end of the abdomen is very membranous and pale and there is no obvious indication of genitalic structures. It is likely that the adults are macropterous (at least in one sex) and that the adult wings are coloured or patterned in some way. Full description and naming must await the collection of adults which, because of the unusual morphological features of the head, should be easily recognized as such, assuming that the adult resembles the nymphs in the unusual head shape described above.

Distribution. Known only from Lord Howe Island.

\section{PHILOTARSIDAE}

\section{Aaroniella howensis Smithers \& Thornton}

Aaroniella howensis Smithers \& Thornton, 1975. Rec. Aust. Mus. 29: 466.

Material studied. $1 n$, eastern slope, Malabar Ridge, above Neds Beach, beating, 25.xi.2000, L. Wilkie, H. Smith.

Distribution. Known only from Lord Howe Island. The only other known specimen is a single female, the first psocopteran collected on the Island.

\section{Haplophallus tandus Smithers \& Thornton}

Haplophallus tandus Smithers \& Thornton, 1975. Rec. Aust. Mus. 29: 468.

Material studied. $1 \delta, 3 q q$, Lagoon Beach between rubbish tip and airstrip, closed rain forest, Drypetes/Cryptocarya, Alyxia ruscifolia, beating, 27.xi.2000, M. Elliott, N. PlunkettCole. 19 , Lagoon Beach between rubbish tip and airstrip, closed rain forest, Drypetes/Cryptocarya, Ochrosia elliptica, beating, 27.xi.2000, M. Elliott, N. Plunkett-Cole. $2 q q$, North Bay, pyrethrum knockdown, 19.xi.1979, G.B. Monteith. 19 , Lord Howe Island, 3-8.ii.1977, C.N. Smithers.

Distribution. Known only from Lord Howe Island. 


\section{ELIPSOCIDAE}

\section{Pentacladus marmoratus Smithers \& Thornton}

Pentacladus marmoratus Smithers \& Thornton, 1975. Rec. Aust. Mus. 29: 462.

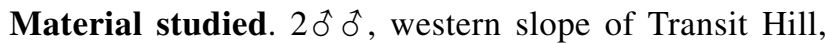
broad megaphyllous closed sclerophyll forest, Howea forsteriana, H. belmoreana, beating, 24.xi.2000, M. Elliott, N. Plunkett-Cole. 1 $\mathrm{o}^{\hat{2}}$, on walking track between Salmon and Kings Beach, dune vegetation, orthophyll short grass, (host H27 in field notes), beating, 10.xii.2000, G. Cassis. 19 , Research Station backyard, surrounded by Drypetes/Cryptocarya, closed rain forest. $2 \hat{0} \widehat{0}$, Stephens Reserve, New Settlement, megaphyllous broad sclerophyll forest, Howea spp. M.S. Moulds. 19 , Lord Howe Island, 3-8.ii.1977, C.N. Smithers.

Distribution. Known only from Lord Howe Island.

\section{Prionotodrilus parvus (Smithers \& Thornton)}

Spilopsocus parvus Smithers \& Thornton, 1975. Rec. Aust. Mus. 29: 465.

Prionotodrilus parvus (Smithers). Schmidt and New, 2004. Invert. Syst. 18: 161.

Material studied. $3 \hat{\sigma} \widehat{\delta}, 1 q$, c. $50 \mathrm{~m} \mathrm{~S}$ of summit of Mt. Eliza on western face, orthophyll short grass, Poa, Cassinia tenuifolia, beating, 1.xii.2000, H. Smith. 19 , point where walking trail first enters Erskine Valley from coast, narrow closed sclerophyll scrub, Melaleuca/Cassinia, Melaleuca howeana, beating, 28.xi.2000, C. Reid, H. Smith. 4 우 + c. $50 \mathrm{~m} \mathrm{~S}$ of summit of Mt. Eliza on western face, orthophyll short grass, Poa, Drypetes deplanchei, beating, 1.xii.2000, H. Smith. $2 q q$, eastern slope of Dawsons Point Ridge near top, closed rain forest, Cleistocalyx/Chionanthus, Drypetes deplanchei, beating, 1.xii.2000, C. Reid, H. Smith. $2 \delta^{\widehat{o}}$, 4 ㅇ ㅇ, c. $50 \mathrm{~m} \mathrm{~S}$ of summit of Mt. Eliza on western face, orthophyll short grass, Poa, Drypetes deplanchei, beating, 1.xii.2000, H. Smith. 19, southern face of Mt. Lidgbird, at base of summit tabletop, closed rain forest, Drypetes/ Cryptocarya (calcarenite), Dysoxylum pachyphyllum, beating, 26.xi.2000, P. Flemons, J. Tarnawski. $1 \hat{\partial}^{\hat{D}}$, Malabar Hill, on path to Kims Lookout, narrow sclerophyll closed scrub, Dodonaea/Cassinia, Cassinia tenuifolia, beating, 24.xi.2000, L. Wilkie, G. Carter. 1 , western slope of Malabar Ridge S of Kims Lookout trail, broad megaphyllous closed sclerophyll forest, Howea belmoreana, beating, 24.xi.2000, L. Wilkie, H. Smith. 10, 1 으, eastern slope of Dawsons Point Ridge above old settlement, closed rain forest, Drypetes/Cryptocarya (exposed), Alyxia ruscifolia, beating, 24.xi.2000, P. Flemons, J. Tarnawski. $20 \hat{0}, 2$ 우 우, eastern slope of Phillip Point (North Head), closed rain forest, Drypetes/Cryptocarya, Drypetes deplanchei, beating, 24.xi.2000, P. Flemons, J. Tarnawski. 1 9 , north bank of Rocky Run Creek where coastal trail to Boat Harbour intersects, broad megaphyllous closed sclerophyll forest,
Pandanus, Metrosideros sclerocarpa, beating, 30.xi.2000, C. Reid, H. Smith. 1 , , Malabar Hill, on path to Kims Lookout, narrow sclerophyll closed scrub, Dodonaea/ Cassinia, Cassinia tenuifolia, beating, 24.xi.2000, L. Wilkie, G. Carter. $4+q$, small swampy area behind dunes at southern end of Lagoon Beach, turnoff to Intermediate Hill, broad sclerophyll swamp scrub, Aegiceras, Lagunaria patersonia (host H15 in field notes), beating, 8.xii.2000, G. Cassis. 19 , Lagoon Beach between rubbish tip and airstrip, closed rain forest, Drypetes/Cryptocarya, Alyxia ruscifolia, beating, 27.xi.2000, M. Elliott, N. PlunkettCole. 10 , southeastern aspect of Transit Hill near summit, closed rain forest, Cleistocalyx/Chionanthus, Xylosma maidenii, beating, 24.xi.2000, M. Elliott, N. Plunkett-Cole. 19 , southeastern aspect of Transit Hill near summit, closed rain forest, Cleistocalyx/Chionanthus, Xylosma maidenii, beating, 24.xi.2000, M. Elliott, N. Plunkett-Cole. 10, western slope of Malabar Ridge S of Kims Lookout trail, broad megaphyllous closed sclerophyll forest, Howea belmoreana, beating, 24.xi.2000, L. Wilkie, H. Smith. $2 \hat{\delta} \boldsymbol{t}$, junction of Kims Lookout trail and North Beach trail, closed rain forest, Drypetes/Cryptocarya, Drypetes deplanchei, beating, 25.xi.2000, L. Wilkie, H. Smith. 1 \% eastern slope of Malabar Ridge above Neds Beach, closed rain forest, Drypetes/Cryptocarya, Dodonaea viscosa, beating, 25.xi.2000, L. Wilkie, H. Smith. 19 , base of Round Face (Mt. Lidgbird), Far Flats, broad megaphyllous closed sclerophyll forest, Howea belmoreana, leaf litter, 27.xi.2000, LHIS. 3 q 9 , Malabar Hill, on path to Kims Lookout, narrow sclerophyll closed scrub, Dodonaea/Cassinia, Drypetes deplanchei, beating, 24.xi.2000, L. Wilkie, G. Carter. 10 , eastern aspect of Transit Hill near summit, narrow closed sclerophyll scrub, Melaleuca/Cassinia, leaf litter, 19.xi.2000, LHIS. 10 , Malabar Hill, on path to Kims Lookout, narrow sclerophyll closed scrub, Dodonaea/Cassinia, leaf litter,

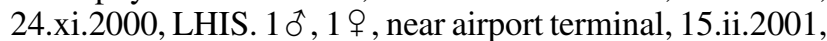
M.S. Moulds. $1 \delta^{\dagger}$, Get Up Place, trail to Mt. Gower, broad closed sclerophyll scrub, Dracophyllum/Metrosideros, Pimelea congesta, beating, 28.xi.2000, C. Reid, H. Smith. 10, Goat House walking track, c. $550 \mathrm{~m}$ from junction with Erskine Valley track, Intermediate Hill, Howea forsteriana, leaf litter, 23.i.2001, J. Tarnawski and M. Shea. 1 ㅇ, Stephens Reserve, New Settlement, megaphyllous broad sclerophyll forest, Howea spp., Drypetes deplanchei, beating, 13.xii.2000, R. Harris. 1 spec. c. $50 \mathrm{~m} \mathrm{~S}$ of summit of Mt. Eliza on western face, orthophyll short grass, Poa, Cassinia tenuifolia, beating, 1.xii.2000, H. Smith. 10, 1 ㅇ, Erskine Valley, rainforest, pyrethrum knockdown, 24.xi.1979, G.B. Monteith. 7 ô ô, 12 우, North Bay, pyrethrum knockdown, 19.xi.1979, G.B. Monteith. 1 ㅇ․ Intermediate Hill, 180-250 m, rainforest, 6.xi.1979, G.B. Monteith. 10 , 1 웅, Malabar Hill, pyrethrum knockdown, 25.xi.1979, G.B. Monteith. 1 으, Creek gully crossing Transit Hill walking track, litter, Cryptocarya triplinervis, Cleistocalyx fullagarii, 9.viii.2001, I. Hutton. 19 , Stephens Reserve, New Settlement, litter under hoop pine, Araucaria cunninghamii, 30.ix.2001, I. Hutton.

Distribution. Known only from Lord Howe Island. 


\section{MYOPSOCIDAE}

\section{Nimbopsocus huttoni n.sp.}

Material studied. $q$ HOLOTYPE (K232524), $49 q$ (not designated paratypes as they are in poor condition), 8 nymphs, on rocks, northern Little Slope, 30.xi.2000, I. Hutton.

Etymology. This species is named for Dr Ian Hutton in recognition of his contribution to knowledge of the natural history of Lord Howe Island.

\section{Description}

Female. Coloration (in alcohol). Head pale brown with pattern of well defined, irregularly-shaped, dark, brown spots. Median epicranial suture pale, flanked on vertex by two rows of spots on each side. Four or five curved rows of spots on each epicranial plate, running almost parallel with inner margin of compound eye. Position of anterior arms of epicranial suture indicated by brown line (anterior arms themselves evanescent). Small brown spot below lower margin of eye behind which is a much larger spot which extends to occupy much of the gena near antenna base. Frons with a dark brown circle. Postclypeus with seven anteriorly converging brown stripes on each side of midline. Anteclypeus and labrum pale except for two small but obvious dark spots on anterior margin of latter. Scape, pedicel and first flagellar segment of antenna pale (antennae incomplete on all specimens). Eyes black. Ocelli black, integument between posterior ocelli pale. Maxillary palps pale except for light brown fourth segment. Mesothoracic antedorsum brown with pale median line; dorsal lobes pale with brown, ovoid area occupying middle part of lobe, median line very dark brown. Mesepisternum mostly dark brown, mesepimeron dark in dorsal part, pale in ventral part. Mesothoracic pleuron mostly pale except for darker area above coxa. Prothoracic legs with pale coxa, femur dark dorsally, irregularly marked laterally; tibia pale, basally and distally brown. Basal tarsal segment pale; second and third segments brown; claws very dark brown. Meso- and metathoracic legs similar to prothoracic legs but coxae laterally dark in basal half. Fore wing (Fig. 19) membrane mostly finely speckled with brown spots; main veins in basal half of wing, other than $\mathrm{Cu} 2$, with alternating lengths of dark and pale sections. Pattern on membrane is of denser spotting near marginal parts of cells R5, M1, M2, and M3. Hind wing membrane very faintly tinged with brown. Small spots at end of veins R1, R2+3; some sections of wing margin between end of R2+3 and M slightly darker than rest of margin. Abdomen ventrally pale, dorsally with strongly developed pattern of irregular, segmentally arranged, very dark brown spots of various sizes.

Morphology. Length of body not measured as all specimens have shrunken abdomens. Median epicranial suture distinct; anterior arms evanescent. Labrum with 8 external proximal sensilla and 7 marginal sensilla. Marginal sensilla consist of 4 trichoid and 3 placoid sensilla. Eyes small, not reaching level of vertex when seen from side. IO/ D: 2.46; PO: 0.61. Ocelli small, anterior ocellus not obvious. Apex of lacinia with smaller inner tooth and bigger, broad outer tooth, apex of which is equipped with several small

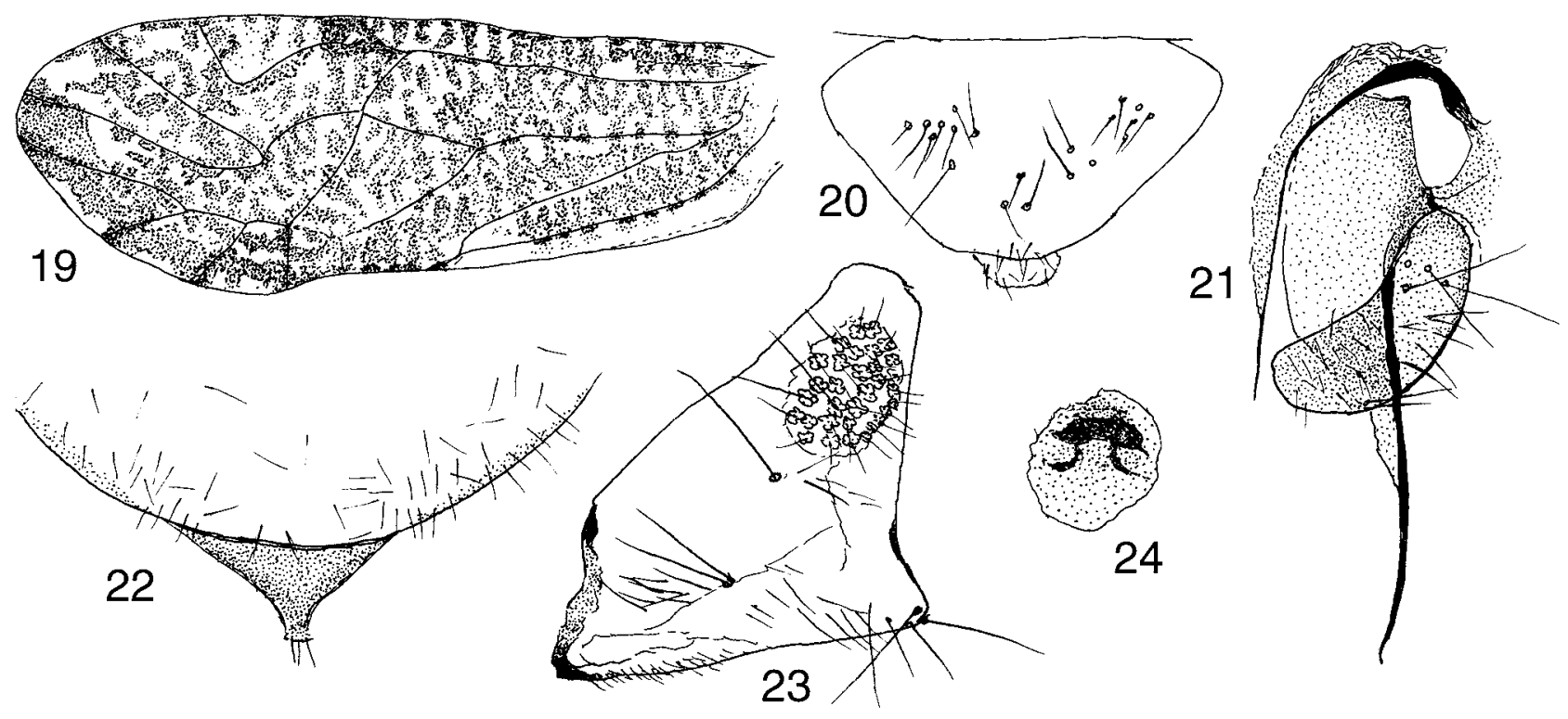

Figs 19-24. Nimbopsocus huttoni n.sp. Female: (19) fore wing; (20) epiproct; (21) gonapophyses; (22) subgenital plate; (23) paraproct; (24) entrance to spermatheca. 
terminal rounded protuberances. Measurements of hind leg: F: 1.17 mm.; T: 1.87 mm.; t1: 0.62 mm.; t2: 0.08 mm.; t3: 0.1 mm.; rt: 7.75:1:1.25; ct. 22, 1, 1. Fore wing length: 5.0 mm.; fore wing width: $1.7 \mathrm{~mm}$. Fore wing (Fig. 19) with Sc present as small, inconspicuous vestige, ending in costal cell. Rs and $\mathrm{M}$ meet in a point or are fused for a short length. Hind wing with Rs distal to separation from M strongly curved towards hind margin of wing then curving forward to division into $\mathrm{R} 2+3$ and $\mathrm{R} 4+5 ; \mathrm{R} 2+3$ reaches wing margin at wing apex. $\mathrm{Rs}$ and $\mathrm{M}$ fused for a length. $\mathrm{M}$ very strongly sinuous. End of $\mathrm{Cu} 1$ strongly recurved near wing margin. Epiproct (Fig. 20) with transverse band of irregularly spaced setae running more or less parallel to curved hind margin and a group of sorter, finer setae near middle of hind margin. Paraproct (Fig. 23). Subgenital plate (Fig. 22, drawn from non-type specimen) with short median posterior lobe bearing 3 terminal setae. Posterior part of plate glabrous, anteriorly plate with fine, scattered setae. Gonapophyses (Fig. 21) with ventral valve short, tapering distally to very fine point. Dorsal valve long, tapering, curved near distal end. Ninth sternite with simple sclerite at entrance to spermatheca (Fig. 24).

Male. Unknown.

Nymphs. Large nymphs are easily recognisable by their head pattern, which is similar to that of adults, the large, characteristic dark spot on the gena below the eye being obvious also in the nymphs. Knobbed glandular setae are present on abdomen and head.

Distribution. Known only from Lord Howe Island.

\section{Discussion}

Despite the lack of information on the male of $N$. huttoni it is placed in the genus Nimbopsocus by virtue of the close similarity of the female genitalia to those of the other species of the genus, especially the form of the sclerifications of the 9th abdominal sternite at the entrance to the spermatheca. The overall mottled wing pattern of $N$. huttoni is made up of much more evenly sized and spaced dark patches than any of the other species in the genus. The black genal patch is large and conspicuous in this species. It has a wing length similar to that of $N$. australis and $N$. thorntoni (female wing length: $5.0 \mathrm{~mm}$ ) which both have longer wings than the smallest species of the genus, $N$. hickmani (female wing length: $3.4-3.6 \mathrm{~mm}$ ).

\section{Nimbopsocus australis (Brauer)}

Psocus australis Brauer, 1865. Ver. zool.-bot. Ges. Wien 15: 908.

Psocus griseipennis McLachlan, 1866. Trans. ent. Soc. Lond. (3rd Series) 5: 348.

Myopsocus griseipennis (McLachlan). McLachlan, 1866. Trans. ent. Soc. Lond. (3rd Series) 5: 352.

Myopsocus australis (Brauer). Kolbe, 1883a. Ent. Nachr. 9: 145.

Myopsocus novaezealandiae Kolbe, 1883a. Ent. Nachr. 9:: 145.

Psocus zealandicus Hudson, 1892. Manual of N.Z. Entomology. London. p. 107.

Phlotodes griseipennis (McLachlan). Enderlein, 1910. Sitzb. Ges. naturf. Fr. Berlin 1910 (2): 67.

[Not Myopsocus australis (Brauer). Tillyard, 1923. Trans. N. Z. Inst. 54: 187].

[Not Myopsocus australis (Brauer). Hickman, 1934. Pap. Proc. $R$. Soc. Tasm. 1933: 85].

[Not Myopsocus griseipennis (McLachlan). Edwards, 1950. Pap. Proc. R. Soc. Tasm (1949): 122.: 104].

Phlotodes australis (Brauer). Smithers \& Thornton, 1974b. Trans. R. ent. Soc. Lond. 126: 125.

Phlotodes novaezealandiae (Kolbe). Smithers \& Thornton, 1974b: 125.

Nimbopsocus australis (Brauer). Smithers, 2004. Thorntoniana, Pub. Espec. UNAM. 20: 159.

Material studied. $1 \%$, Stevens Reserve, nr. Signal Point, yellow pan trap, 8-12.xii.1988, D.C.F. Rentz. Specimen in Australian National Insect Collection.

Distribution. First record for Lord Howe Island. Previously known from Australia, Tasmania, Norfolk Island, New Zealand, Solomon Islands, Kermadecs, ?India. The presence of this species in India requires confirmation. Found mainly on bark, cut timber and paling fences carrying algal and fungal growth. 
ACKNOWLEDGMENTS. I would like to thank Professor E.L. Mockford for helpful discussion of the spermathecal structures of Lepolepis species and on the family placing of Trogium nigrum, those responsible for collecting and sorting the many specimens, Elizabeth Jefferys for pointing out discrepancies in botanical nomenclature, Lance Wilkie for providing electronically handled collection data and Gerry Cassis for making the Lord Howe Island collections available for study.

\section{References}

Badonnel, A., 1931. Contribution à létude de la faune du Mozambique. Voyage de M. P. Lesne (1928-1929). 4e note. Copéognathes. Annales des Sciences naturelles, Zoologie (10)14(16): 229-260, 37 figs.

Badonnel, A., 1932. Contribution à létude de la faune du Mozambique. Voyage de M.P. Lesne (1928-1929). 7e note. Supplement aux Copeognathes. Bulletin de la Societe zoologique de France. 57: 105-117, 14 figs.

Badonnel, A., 1943. Psocoptères. Faune de France 42: 1-164, 375 figs.

Badonnel, A., 1944. Contribution à létude des Psocoptères de l'Atlantide. Revue française d'Entomologie 11: 47-60, 22 figs.

Badonnel, A., 1949. Psocoptères de la Côte d'Ivoire. Mission Paulian-Delamare (1945). Revue française d'Entomologie 16: 20-46, 61 figs.

Badonnel, A., 1955. Psocoptères de l'Angola. Publicacões culturais da Companhia de Diamantes de Angola 26: 1-267, 625 figs.

Banks, N., 1900. A new genus of Atropidae. Entomological News 11: 431-432, figs (not numbered) on p. 431.

Brauer, F., 1865. Vierter Bericht über die auf der Weltfahrt der kais. Fregatte Novara gesammelten Neuropteren. Verhandlungen der Zoologisch-Botanischen Gesellschaft in Wien 15: 903-908.

Brauer, F., \& F. Löw, 1857. Neuroptera austriaca. Wien. XXIII+80 pp., 5 pls (Psoc.: pp. 32-34).

Broadhead, E., 1949. On the identity of the psocid Cuixa canaria Navás. Entomologists Monthly Magazine 85: 80.

Corbett, G.H., \& E. Hargreaves, 1915. Vulturops floridensis, a new member of the psocid subfamily Vulturopinae from the United States. Psyche 22(4): 142-143, pl. XI.

Edwards, B.A.B., 1950. A study of the Tasmanian Psocoptera with descriptions of new species. Papers and Proceedings of the Royal Society of Tasmania (1949): 93-134, 117 figs.

Enderlein, G., 1903. Neue Copeognathen aus Kamerun. Zoologische Jahrbücher (Abteilung Systematik) 19: 1-8, pl. 1.

Enderlein, G., 1905. Morphologie, Systematik und Biologie der Atropiden und Troctiden, sowie Zusammenstellung aller bisher bekannten recenten und fossilen Formen. Results of the Swedish Zoological Expedition to Egypt and the White Nile, 1901. No.18. 58 pp., 11 figs, 4 pls.

Enderlein, G., 1908. Über die Variabilität des Flügelgeäders der Copeognathen. Zoologischer Anzeiger 33: 779-782, 12 figs.

Enderlein, G., 1910. Eine Dekade neuer Copeognathengattungen. Sitzungsberichte der Gesellschaft naturforschender Freunde zu Berlin 1910(2): 63-77, 10 figs.

Enderlein, G., 1911. Die fossilen Copeognathen und ihre Phylogenie. Palaeontographica 58: 279-360, figs A-S; pls XXI-XXVII (figs 1-103).

Gurney, A.B., 1949. Distributional and synonymic notes on psocids common to Europe and North America, with remarks on the distribution of Holarctic insects (Corrodentia). Journal of the Washington Academy of Sciences 39(2): 56-65.

Hagen, H., 1861. Synopsis of the Neuroptera of North America; with a list of South American species. Smithsonian Miscellaneous Collections 4: XX+347 pp. (Psoc.: pp. 7-14, 302).

Hagen, H., 1865. Synopsis of the Psocina without ocelli. Entomologists Monthly Magazine 2: 121-124.

Hagen, H., 1883. Beiträge zur Monographie der Psociden. Stettiner Entomologische Zeitung 44: 285-332.
Hickman, V.V., 1934. A contribution to the study of Tasmanian Copeognatha. Papers and Proceedings of the Royal Society of Tasmania 1933: 77-89, 6 figs.

Hudson, G.V., 1892. An elementary Manual of New Zealand Entomology. London. 122 pp., frontis., 20 pls (Psoc.: p. 107, pl. XVI, figs 2, 2a).

Jacobson, G.G., \& W.L. Bianchi, 1904. Die Orthopteren und Pseudoneuropteren des Russischen Reiches und der angrenzenden Länder. Petersburg. (Psoc.: pp. 482-496, 48 figs).

Kolbe, H.J., 1880. Monographie der deutschen Psociden mit besonderer Berücksichtigung der Fauna Westfalens. Jahresbericht des Westfälischen Provinzial-Vereins für Wissenschaft und Kunst 8: 73-142, pls I-IV.

Kolbe, H.J., 1881. Psocidologische Berichtigungen. Entomologische Nachrichten, Berlin 7: 254-256.

Kolbe, H.J., 1882. Neue Psociden der paläarktischen Region. Entomologische Nachrichten, Berlin 8: 207-212.

Kolbe, H.J., 1883a. Ueber das Genus Myopsocus und dessen Species. Entomologische Nachrichten, Berlin 9: 141-146.

Kolbe, H.J., 1883b. Neue Psociden des Königl. zoologischen Museums zu Berlin. Stettiner Entomologische Zeitung 44: 65-87.

Kolbe, H.J., 1885. Zur Kenntniss der Psociden-Fauna Madagaskars. Berliner Entomologische Zeitschrift 29: 183-192, pl. IVB.

Kolbe, H.J., 1888. Psocidae. In Neuroptera germanica. Die Netzflügler Deutschlands, mit Berücksichtigung auch einiger ausserdeutschen Arten nach der analytischen Methode unter Mitwirkung von H. Kolbe bearbeitet, M. Rostock. Jahresbericht des Vereins für Naturkunde zu Zwickau 1887: 1-198, pls I-X.

Lienhard, C., 1998. Psocoptères euro-mediterranéens. Faune de France 83: $\mathrm{xx}+517$ pp., 148 figs, 11 pls.

Lienhard, C., \& J. Halperin, 1988. Preliminary list of Psocoptera from Israel with description of two new species. Israel Journal of Entomology 22: 13-25, 7 figs.

Lienhard, C., \& C.N. Smithers, 2002. Psocoptera (Insects). World Catalogue and Bibliography. Instrumenta Biodiversitatis 5: xli+745 pp. Muséum d'Histoire naturelle, Genève.

Li Fasheng, 1993. Psocoptera from National Chebaling Nature Reserve (Insecta: Psocoptera). In Collected Papers for Investigation in National Chebaling Nature Reserve, pp. 313-430, 104 figs, col. pl. 2: figs 1-3. Science and Technology Publishing House of Guangdong Province. (In Chinese, with English summary).

McLachlan, R., 1866. New genera and species of Psocidae. Transactions of the Entomological Society of London (Third Series) 5: 345-352.

Mockford, E.L., 1984. Relationships among Philotarsid and Pseudocaeciliid genera and a proposed new family Bryopsocidae (Psocoptera). Psyche, Cambridge, Massachusetts 91(3-4): 309-318, 3 figs.

Mockford, E.L., 1993. North American Psocoptera (Insecta). Flora and Fauna Handbook 10: XVIII+455 pp., 953 figs. Gainesville, Florida: Sandhill Crane Press.

Mockford, E.L., 2000. A classification of the psocopteran family Caeciliusidae (Caeciliidae auct.). Transactions of the American Entomological Society 125(4) (1999): 325-417, 238 figs. [Publication date: January 2000].

Mockford, E.L., 2005. A new genus of Perientomine Psocids (Psocoptera: Lepidopsocidae) with a review of the Perientomine genera. Transactions of the American entomological Society 131: 201-215, 32 figs.

Motschulsky, V. von, 1851. Énumérations des nouvelles espèces des Coléoptères rapportés par M. Victor Motschulsky de son dernier voyage. Bulletin de la Société Impériale des Naturalistes de Moscou 24(2): 479-511, 1 fig. (Psoc.: pp. 510-511).

Navas, L., 1927. Insetti raccolti nel Porto di Genova sulle Banane delle Canarie. Bolletino della Società Entomologica Italiana 59: 150-152, 2 figs.

New, T.R., 1973. New species and records of Peripsocus Hagen (Psocoptera, Peripsocidae) from south east Australia. Journal of the Australian Entomological Society 12: 340-346, 16 figs. 
Obr, S., 1948. A la connaissance des Psocoptères de Moravie (Tchècoslovaquie). Spisy vydavane Prirodovedeckou Fakultou Masarykovy University M2 306: 108 pp., 196 figs. (Publications de la Faculté des Sciences de l'Université Masaryk).

Pickard, J., 1983. Vegetation of Lord Howe Island. Cunninghamia 1: $133-266$.

Ribaga, C., 1899. Descrizione di un nuovo genere e di una nuova specie di Psocidi trovato in Italia. Rivista di Patologia Vegetale 8: 156-159, pl. 7.

Roesler, R., 1943. Über einige Copeognathengenera. Stettiner Entomologische Zeitung 104: 1-14, 13 figs.

Schmidt, E.R., \& T.R. New, 2004. A systematic and phylogenetic revision of the family Elipsocidae (Insecta: Psocoptera), with the erection of two new families: Lesniidae and Sabulopsocidae. Invertebratae Systematics 18: 157-213, 113 figs, 2 Appendices.

Schmidt, E.R., \& C.N. Smithers, 2004. The genus Howeanum Smithers (Psocoptera: Elipsocidae) transferred to the Family Pseudocaeciliidae. General and applied Entomology 33: $13-14$.

Schmidt, E.R., \& I.W.B. Thornton, 1993. The Psocoptera (Insecta) of Wilsons Promontory National Park, Victoria, Australia. Memoirs of the Museum of Victoria 53(2) (1992): 137-220, 249 figs.

Smithers, C.N., 1967. A Catalogue of the Psocoptera of the World. Australian Zoologist 14(1): 1-145.

Smithers, C.N., 1977. The Psocoptera of Muogamarra Nature Reserve. Records of the Australian Museum 31(7): 251-306, 98 figs.

Smithers, C.N., 1978. A new species and new records of Psocoptera (Insecta) from Ireland. Irish Naturalists Journal 19(5): 141-148, 8 figs.

Smithers, C.N., 1979. An additional record and key to the Psocoptera (Insecta) of Lord Howe Island. Australian entomological Magazine 6(2): 21-22.

Smithers, C.N., 1994a. A note on the Peripsocidae (Psocoptera) of Tuglo Wildlife Refuge, Hunter Valley, New South Wales. Australian Entomologist 21(1): 7-10, 4 figs.

Smithers, C.N., 1994b. Generic positions of Australian Psocoptera currently placed in Paracaecilius Badonnel and Enderleinella Badonnel (Insecta: Psocoptera: Caeciliidae). Records of the Australian Museum 46: 125-129, 12 figs.

Smithers, C.N., 1995. Psocoptera from the inflorescences of

Howea forsteriana. (Moore and F.J. Muell.) Becc. (Arecaceae)

(Thatch Palm) on Lord Howe Island. General and applied Entomology 26: 2-8. 20 figs.

Smithers, C.N., 1996. Psocoptera. In Zoological Catalogue of Australia, ed. A. Wells, 26: 1-79, 363-372 (index). Melbourne, Australia: CSIRO Publishing.

Smithers, C.N., 2003. The identity and nomenclature of some species of Ectopsocus McLachlan (Psocoptera: Ectopsocidae) common to the Palaearctic, Nearctic and Australasian Regions. Entomologists monthly Magazine 139: 1-6.

Smithers, C.N., 2004. A new genus for three species of Australian Myopsocidae (Psocoptera). In: Thorntoniana. A commemorative volume for Ian W.B. Thornton. Publicaciones Especiales, ed. A.N. Garcìa Aldrete, C. Lienhard and E.L. Mockford, 20. Mexico: Instituto de Biologia, UNAM.
Smithers, C.N., \& E.L. Mockford, 2004. A new genus of Psoquillidae (Psocoptera) for Trogium nigrum Smithers. Entomologists monthly Magazine 140: 313-315, 3 figs.

Smithers, C.N., J.V. Peters \& I.W.B. Thornton, 2000. The Psocoptera (Insects) of Norfolk and Phillip Islands: Occurrence, Status and Zoogeography. Proceedings of the Linnean Society of new South Wales 121: 101-111. (An errata sheet correcting important printer's errors made after proof-reading, appeared in Proceedings of the Linnean Society New South Wales 122: page not numbered [2000]).

Smithers, C.N., \& I.W.B. Thornton, 1974a. The Psocoptera (Insecta) of Norfolk Island. Records of the Australian Museum 29(8): 209-234, figs 1-67.

Smithers, C.N., \& I.W.B. Thornton, 1974b. The Myopsocidae (Psocoptera) of New Guinea and New Caledonia. Transactions of the Royal entomological Society of London 126(1): 91-127, 95 figs.

Smithers, C.N., \& I.W.B. Thornton, 1975. The Psocoptera (Insecta) of Lord Howe Island. Records of the Australian Museum 29(16): 453-472, 54 figs.

Tetens, H., 1891. Zur Kenntnis der deutschen Psociden. Entomologische Nachrichten, Berlin 17: 369-384.

Thornton, I.W.B., 1959. New species of Peripsocus Hagen, 1866 (Corrodentia: Peripsocidae) from Hong Kong Island, with further descriptions of Peripsocus similis Enderlein, 1903 and Peripsocus quercicola Enderlein, 1906. Proceedings of the Royal Entomological Society of London (B) 28(3/4): 37-48, 18 figs.

Thornton, I.W.B., \& S.K. Wong, 1968. The Peripsocid fauna (Psocoptera) of the Oriental region and the Pacific. Pacific Insects Monographs 19: 1-158, 302 figs.

Tillyard. R.J., 1923. A monograph of the Psocoptera, or Copeognatha, of New Zealand. Transactions of the New Zealand Institute 54: 170-196, 20 figs, pl. 18.

Turner, B.D., 1977. Moroccan Psocoptera-a new Cerobasis species and a redescription of Ectopsocus strauchi Enderlein. Journal of Natural History 11: 281-287, 6 figs.

Wilson, A.G., ed., 1994. Flora of Australia, vol. 49, Oceanic Islands 1. Canberra: Australian Government Publishing Service.

Yoshizawa, K., 2000. Redescription of Mepleres suzukii (Okamoto), with comments on synonymy among Mepleres, Pseudoscottiella and Meniscopsocus (Psocodea: Psocoptera: Pseudocaeciliidae). Entomological Science 3(4): 669-674, 2 figs.

Zimmerman, E.C., 1948. Insects of Hawaii. Honolulu. [Psoc. (Corrodentia): vol. 2, pp. 217-252, figs 121-137].

Manuscript submitted 21 July 2005, revised 22 May 2006 and accepted 5 October 2006.

Associate Editor: M.S. Moulds. 